University of Florida Levin College of Law

UF Law Scholarship Repository

UF Law Faculty Publications

Faculty Scholarship

1996

\title{
Reverence for Life and Environmental Ethics in Biblical Law and Covenant
}

Richard H. Hiers

University of Florida Levin College of Law, rhiers@ufl.edu

Follow this and additional works at: http://scholarship.law.ufl.edu/facultypub

Part of the Religion Law Commons

\section{Recommended Citation}

Richard H. Hiers, Reverence for Life and Environmental Ethics in Biblical Law and Covenant, 13 J.L. \& Religion 127 (1996), available at http://scholarship.law.ufl.edu/facultypub/738

This Article is brought to you for free and open access by the Faculty Scholarship at UF Law Scholarship Repository. It has been accepted for inclusion in UF Law Faculty Publications by an authorized administrator of UF Law Scholarship Repository. For more information, please contact outler@law.ufl.edu. 


\title{
REVERENCE FOR LIFE AND ENVIRONMENTAL ETHICS IN BIBLICAL LAW AND COVENANT
}

\author{
Richard H. Hiers ${ }^{\dagger}$
}

\section{INTRODUCTION}

The Bible is generally recognized as the foundation and point of departure for later Jewish and Christian religious and moral understandings. Nevertheless, both conservative and liberal schools within these traditions have tended to assume that biblical religion has to do only with humankind.' philosophy likewise has been pre-occupied exclusively with the human situation. ${ }^{2}$ In recent years, many theologians and ethicists

$\dagger$ Professor of Religion, Affiliate Professor of Law, and Affiliate Professor, College of Natural Resources and Environment, University of Florida, Gainesville, Florida 32611. rhiers@religion.ufl.edu.

In recent years, Professor Sturm has focused increasingly on environmental (or ecological) ethics and the value of individual creatures of all species. He hinted at this turn in his 1988 book, Community and Alienation: Essays on Process Thought and Public Life 134, 232-33, 236 (U of Notre Dame Press, 1988). Next, in The Idea of Human Rights: A Communitarian Perspective, 23 Process Studies, 238-55 (1994), Sturm proposed to shift human rights from its 18 century, independent, individualistic ontology to a "natural rights" groundwork embracing "the community of life" inclusively. Here he urged, "[T] he idea of natural rights properly provokes concern for whole species and for interdependent ecosystems as well as for individual organisms." Id at 252 . Two quite recent essays directly address ecological or biosphere ethics with characteristic intensity and insight: Faith, Ecology, and the Demands of Social Justice: On Shattering the Boundaries of Moral Community, in Donald A. Crosby and Charley D. Hardwick, eds, Religious Experience and Ecological Responsibility (P. Lang, 1996), and Koinonology and Ecological Principle, written as an epilogue to his book, Solidarity and Suffering (SUNY Press, 1998).

1. See Lynn White, Jr.'s oft-cited contention in The Historical Roots of Our Ecologic Crisis, 155 Science 1205 (1967): "God planned all [creation] explicitly for man's benefit and rule; no item in the physical creation had any purpose save to serve man's purposes." Others, too, criticized biblical texts for neglecting the value of non-human life forms. See, for example, Steven C. Rockefeller, Faith and Community in an Ecological Age, in Steven C. Rockefeller and John C. Elder, eds, Spirit and Nature 148 (Beacon Press, 1992): "[T]he purpose of the creation of the universe is the establishment of a kingdom of God on earth by and for human beings." Id. As to the "Christian Right's" neglect of biblical environmental concerns, see Chuck D. Barlow, Why the Christian Right Must Protect the Environment, 23 BCEnv Affairs L Rev 781-91 (1996).

2. See generally, Albert Schweitzer, The Philosophy of Civilization (Macmillan, 1959); Gene McAfee, Ecology and Biblical Studies, in Dieter T. Hessel, ed, Theology for Earth Community: A Field Guide 31-44 (Orbis Books, 1996). Notable exceptions include Bentham, 
have begun to trace the roots of emerging environmental concerns back to biblical sources. Several excellent studies have resulted from this movement. ${ }^{3}$ None, however, has focused on biblical laws and covenants.

Commonly, biblical laws are thought to refer solely to Israel's relation with God (or Yahweh) ${ }^{4}$ and the structuring of relationships within the Israelite community. The term "covenant" generally refers to those reported occasions in biblical times when God designated Abraham, Isaac, Jacob, and their descendants, as his particular people, and laid upon them certain obligations, typically in the form of laws. Yet a great many biblical laws refer to treatment of animals, the land, trees, and vegetation. And two major biblical covenants embrace not only the people of Israel, but all human beings and all living creatures.

This article undertakes to examine these covenants and those biblical laws concerning human relations with the earth and the various life forms whose habitat it provides. Of course biblical texts do not all speak with a common voice. These texts include differing, and even conflicting perspectives and understandings. However, biblical law and covenant show much greater concern for the wellbeing of "the environment" and all living things than either proponents or critics of Judaism and Christianity generally have recognized. Many other biblical texts also are relevant to the subject of this article; some of these are noted as background. Because it renders the Hebrew (and other ancient biblical languages) more

Mill, Montaigne, Paine, and Voltaire. See Mary Midgley, Animals and Why They Matter 11 (U of GA Press, 1984).

3. See, for example, Bernhard W. Anderson, From Creation to New Creation: Old Testament Perspectives (Fortress, 1994); Richard Cartwright Austin, Hope for the Land: Nature in the Bible (John Knox Press, 1987); James Barr, Man and Nature: The Ecological Controversy and the Old Testament, 52 Bulletin of the John Rylands Library 9-32 (1972); Wendell Berry, The Gift of the Good Land: Further Essays, Cultural and Agricultural 267-81 (North Point Press, 1981); Robert R. Gottried, Economics, Ecology, and the Roots of Western Faith 29.65 (Rowman and Littlefield, 1995); Bruce J. Malchow, Contrasting Views of Nature in the Hebrew Bible, 26 Dialog 40-43 (1987); Holmes Rolston III, The Bible and Ecology, 50 Interpretation 16-26 (1996); H. Paul Santmire, The Travail of Nature: The Ambiguous Ecological Promise of Christian Theology, ch 10 (Fortress, 1985); Ronald A. Simkins, Creator and Creation: Nature in the Worldview of Ancient Israel (Hendrickson Publishers, 1994); and Odil Hannes Steck, World and Environment (Abingdon, 1980). Over 700 titles are listed in Hessel's Bibliography. See Hessel, ed, Theology for Earth Community at 269-92 (cited in note 2). See generally Robert Booth Fowler, The Greening of Protestant Thought $28-44$ (U of NC Press, 1995).

4. The divine name YHWH, possibly vocalized as "Yahweh" (if not Jehovah), appears throughout much of the biblical tradition. English Bibles usually render this name as "The LORD." See note 30. 
literally than other modern translations, the Revised Standard Version is generally followed when texts are quoted.

The results of this study are set out thematically, beginning with the primordial commandments to early humankind in the first chapters of Genesis (Part II). Then follows an account of the covenant between God and "every living creature" articulated in Genesis nine (Part III). After this, comes a brief introduction to the major biblical law codes (Part IV). Part V examines Biblical laws relating to animal sacrifices. Laws that specifically indicate concern for humane treatment of animals are considered in part VI. Part VII reviews other laws affecting animals. Part VIII has to do with the "land ethic" implicit in several Biblical laws. Part IX concerns laws relating to trees and other vegetation. And Part $X$ focuses on the prophet Hosea's promise that in the coming or messianic age, YHWH would establish a new covenant with all living creatures, along with related texts in Isaiah.

\section{THE PRIMORDIAL COMMANDMENTS TO "BE FRUITFUL AND MULTIPLY," TO "FILL AND SUBDUE THE EARTH;" TO HAVE \\ "DOMINION" OVER OTHER LIVING CREATURES; AND TO REFRAIN FROM EATING THE "LIFE" OF LIVING CREATURES.}

Most biblical laws are found in the books of Exodus, Numbers, Leviticus, and Deuteronomy, where they are said to have been mediated by Moses to Israel during its sojourn in the Sinai Peninsula. However, several other laws, commands, or instructions appear in the book of Genesis, particularly the first nine chapters. As the story is told, these were for the guidance and direction of the early forebears of all humankind-and also the forebears of all other animate living beings.

Near the end of the "P" or Priestly" creation story (Gen 1:1-

5. "P" is the symbol used by biblical scholars for more than a century to designate the socalled "Priestly" traditions found in the "books" of Genesis, Exodus, Leviticus, and Numbers. These traditions are thought to derive from writers and editors associated with the priests who officiated at the Jerusalem Temple in the late sixth or fifth centuries B.C.E. Typical emphases include the distinction between priests ("the sons of Aaron") and Levites (here seen as assistants to the priests); genealogies, especially of priestly and Levitical families; ceremonial furnishings of the "tabernacle" or "tent of meeting" (conceived as a portable prototype of the eventual Jerusalem temple); and, detailed instructions as to carrying out numerous kinds of sacrificial offerings. In Genesis, texts attributed to $P$ characteristically use the divine name Elohim, translated as "God." As to P tradition in Genesis $1-10$, see generally Steck, World and Environment at 89-113 (cited in note 3); and Gerhard von Rad, 1 Old Testament Theology 232.79 (Harper, 1962). 
2:4a), the first man and woman were "blessed" by God and ordered (or authorized) to "[b]e fruitful and multiply, and fill the earth and subdue it," and to have "dominion" over other living creatures. (1:26-28). ${ }^{6}$ In recent years, many morally serious writers have urged that Judaism and Christianity are to be blamed for the contemporary environmental crisis because religious and non-religious people throughout the world in ensuing centuries allowed themselves to be guided by these and other biblical mandates. ${ }^{7}$ This kind of complaint fails to take seriously the biblical context in which the primordial pair were so instructed. ${ }^{8}$ According to Genesis 1:26-28, only the aboriginal man and woman were authorized to subdue the earth and have dominion. Moreover, everything in Genesis one preceded the time of the great flood (Gen 6-9), after which the whole structure of relations among humans, other creatures, and God was altered radically. It therefore seems likely that these commands were understood to have applied only to conditions during that antediluvian era. Curiously, many critics and proponents of biblical perspectives sometimes seem unaware that the Bible continues beyond Genesis one and has considerably more to say about environmental issues."

6. Simkins. notes that there is no biblical basis for the often-repeated assertion that the first man's naming other animals (Gen 2:18-20) signified human superiority or dominance over them. Simkins, Creator \& Creation at 183 (cited in note 3).

7. For a variety of critiques and responses by other commentators, see, for example, Ian Barbour, II Ethics in an Age of Technology 74-80 (Harper Collins, 1993); Jeremy Cohen, On Classical Judaism and Environmental Crisis, 5 Tikkun No. 27477 (1990); Thomas S. Derr, Environmental Ethics and Christian Humanism 19-22 (Abingdon Press, 1996); Dale and Sandy Larsen, While Creation Waits: A Christian Response to the Environmental Challenge 43-54 (Harold Shaw Publishers, 1992); James A. Nash, Loving Nature: Ecological Integrity and Christian Responsibility 68-92 (Abingdon Press, 1991); Gary North, The Dominion Covenant: Genesis 27-36 (Institute for Christian Economics, 1982); and John Arthur Passmore, Man's Responsibility for Nature; Ecological Problems and Western Traditions 3-27 (Charles Scribner's Sons, 1974).

8. It also tends to over-estimate the impact of these biblical texts on cultures where Judaism, Christianity, and their scriptures have had little or no identifiable influence. And it under-estimates the influence of other and more plausible factors. See Barry Commoner, The Closing Circle: Nature, Man \& Technology 1-6 (Knopf, 1971); Rene Jules Dubos, A God Within 160-62 (Scribner, 1972). Emest L. Fortin, The Bible Made Me Do It: Christianity, Science, and the Environment, 57 Rev of Politics 197-223 (1995); Jim Mason, An Unnatural Order: Uncovering the Roots of Our Domination of Nature and Each Other (Simon \& Schuster, 1993); Alan S. Miller, A Planet to Choose: Value Studies in Political Ecology 67-74 (Pilgrim Press, 1978); Nash, Loving Nature at 75 (cited in note 7); Colin Archibald Russell, The Earth, Humanity, and God 86-93 (UCL Press, 1994); and Steck World and Environment at 3142 (cited in note 3 ).

9. This point has been noted also by Bernhard W. Anderson, "Creation and Ecology," in Creation in the Old Testament 152-171 (Fortress Press, 1984). 
Nevertheless, a great deal of scholarly attention has been devoted to interpreting Genesis 1:26-28, which verses seem to have instructed the first human couple to "subdue" the earth and "have dominion over" other creatures. Some interpretations emphasize human stewardship or responsibility for tending the garden and caring for the well-being of other creatures; others read these verses as legitimating exploitation of the earth's resources and other life forms for human benefit. ${ }^{10}$ Whatever one makes of these texts, many other biblical laws call on humans to respect the earth and care positively for other creatures' well-being. And major biblical covenants leave no doubt that God was understood to be concerned for the well-being of all life forms, not only for that of humans."

Before the flood, as the Genesis story unfolds, men (and necessarily women) already had multiplied (6:1); and the earth had become "filled with violence" (6:11), meaning, evidently, with violent human beings. ${ }^{12}$ Perhaps the narrator understood that such violence

10. See, for example, Paul Abrecht et al., Faith, Science and the Future 34-43 (Fortress Press, 1979); Anderson, From Creation to New Creation at 111-31 (cited in note 3); Phyllis A. Bird, "'Male and Female He Created Them': Genesis 1:27b in the Context of the Priestly Act of Creation," 74 Harv Theological Rev 137-44 (1981); Berry, The Gift of the Good Land at 268-69 (cited in note 4); J. Baird Callicott, Genesis and John Muir, in Carol S. Robb \& Carl J. Casebolt, eds., Covenant for a New Creation: Ethics, Religion and Public Policy 107-40 (Orbis Books, 1991); Douglas John Hall, Imaging God: Dominion as Stewardship (Friendship Press, 1986); Gottfried, Economics, Ecology and the Roots of Western Faith at 36-39 (cited in note 3); Wesley Grandberg-Michaelson, $A$ Worldly Spirituality: The Call to Redeem Life on Earth (Harper \& Row, 1984); Tom Hayden, The Lost Gospel of the Earth 60-66, 81-102 (Wolfhound Press, 1996); Diane Jacobson, Biblical Bases for Eco-Justice Ethics, in Hessel, ed., Theology for Earth Community at 46-49; James Limburg, The Way of an Eagle in the Sky: Reflections on the Bible and the Care of the Earth, Catholic World 148-52 (July/Aug. 1990); Nash, Loving Nature at 102-8 (cited in note 7); Holmes Rolston, III, Environmental Ethics: Duties to and Values in the Natural World 338 (Temple U. Press, 1988); Steck, World and Environment at 102-08, 194 200 (cited in note 3); Lloyd H. Steffen, In Defense of Dominion, 14 Environmental Ethics 63 80 (1992); Phyllis Trible, Ancient Priests and Modern Pollution, 12 Andover Newton Q 74-79 (1971); Gene M. Tucker, Rain on a Land Where No One Lives: The Hebrew Bible on the Environment, $116 \mathrm{~J}$ of Biblical Literature 3-17 (1997); and Loren Wilkinson, ed., Earthkeeping in the Nineties: Stewardship of Creation 275-325 (rev. ed, William B. Eerdmans Pub. Co., 1991). As to the nature and somewhat limited extent of Jewish responses, see Ismar Schorsch, Learning to Live with Less: A Jewish Perspective, in Rockefeller \& Elder, eds, Spirit and Nature at 25-38 (cited in note 1); and Eilon Schwartz, Jewish Theory and the Environmental Crisis in Hessel, ed., Theology for Earth Community at 53-63 (cited in note 2).

11. See parts III and X. And see generally Charles S. McCoy, Creation and Covenant: $A$ Comprehensive Vision for Environmental Ethics, in Robb and Cvasebolt, eds., Covenant for a New Creation at 212-25 (cited in note 10).

12. See Gen 6.5, which characterizes the human condition before the flood: "YHWH saw that the wickedness of man was great in the earth, and that every imagination of the thoughts of his heart was only evil continually." Arguably, the P account at Gen 6:11-22 likewise attributes "violence" to humanity, not to other creatures, though other creatures somehow 
derived, at least in part, from humans abusing their authority to subdue and dominate. At any rate, humankind had gotten out of hand. As a result of the flood, the human population was reduced to a small group once again, now consisting of Noah and his immediate family. After the flood, God instructs this inchoate human community, "Be fruitful and multiply, and fill the earth." $(9: 1,7)$. This time, significantly, nothing is said about humans subduing the earth or having dominion over other creatures. It is not certain that $P$ tradition understood that the aboriginal commands as to "subduing" and "dominion" were to apply in the era following the flood. ${ }^{13}$ Moreover, numerous biblical texts recognize that in postdiluvian times, humankind's domination over other creatures was qualified or limited. ${ }^{14}$ Furthermore, biblical tradition typically maintains that it is God (or Yahweh) who has dominion over both history and all creation. ${ }^{15}$ As the biblical narrative stands, humans had authority to subdue the earth and have dominion over other living things only in the primordial period before the flood.

After the flood, Noah and his sons were again told (or

may have been corrupted by human depravity. See Bernhard W. Anderson, Creation and Ecology, in Bernard W. Anderson, ed., Creation in the Old Testament 161-65 (Fortress, 1984). Contrast Steck, World and Environment (cited in note 3), pointing out that nothing in the biblical narrative suggests that humans had been threatened or harmed by violent animals.

13. Granberg-Michaelson notes that after the flood, repetition of these commands was "conspicuously omitted." Granberg-Michaelson, $A$ Worldly Spirituality at 64 (cited in note 10). The author of Psalm 8:5-8, however, may represent a strand of biblical understanding to the effect that humans were to have dominion over other life forms in the era after the flood. The character of such dominion is not indicated in the psalm. See Elizabeth Dodson Gray, $A$ Critique of Dominion Theology, in Dieter T. Hessel, ed., For Creation's Sake: Preaching, Ecology, and Justice 71-83 (Geneva Press, 1985); and James B. Tubbs, Jr., Humble Dominion, in 50 Theology Today 543-56 (1994). In the NT, Psalm eight is read as a prophetic description of Christ's not humankind's rule or dominion: Eph 1:20-22; Heb 2:5-10.

14. In Job 40 , YHWH urges that Job (and, implicitly, other humans) cannot hope to subdue the great creatures Behemoth and Leviathan. Several other texts in Job and Psalms make clear that many creatures for whom YHWH cares were meant to remain free from human control. See, for example, Job 38:39-41; 39:1-12, 26-30; Psalms 50:9-12; 104:10-13, 17$18,20-22,24-30 ; 145: 13-16$; and 147:8-9. See generally Tucker, $116 \mathrm{~J}$ of Biblical Literature (cited in note 10). On the Book of Job as a critique of anthropocentrism, see Hayden The Lost Gospel of the Earth at 74-81 (cited in note 10). On Psalm 104, see Steck, World and Environment at 78-89 (cited in note 3). See Barlow 23 BC Env Affairs L Rev at 802 (cited in note 1). The absence of humankind's dominion as a theme in the remainder of the Old and New Testaments reflects the loss of humankind's status as dominator of the earth. Id. See also Nash, Loving Nature at 102 (cited in note 7).

15. See, for example, Judges 2:11-23; 1 Kings 11:26-39; 2 Kings 17:1-18; 24:18-20; Job 38:4-39:8; Psalms 90-91; 94; 96-99; 135:5-12; 145:13; Amos 1-3; Jonah; and all other biblical prophets. See generally, McAfee, Ecology and Biblical Studies at 36-38 (cited in note 2). In some texts, other creatures are said to have dominion over humans. See generally, Jeanne Kay, Concepts of Nature in the Hebrew Bible, 10 Environmental Ethics 309, 31417 (1988). 
commanded) to be "fruitful and multiply and fill the earth." (Gen 9:1,7). This "commandment" was addressed to Noah and his family in the context of the situation immediately after the flood which had destroyed all other human life. It meant that the human race could start all over again. It was not presented as an ordinance or prescription binding upon all humanity in later eras. Nor is it repeated, or even alluded to, in later biblical traditions or periods. According to Genesis 9:19, the whole earth had already been "peopled" by Noah's descendants, at least by the time the author or editor was writing. Perhaps the Genesis narrators understood that, so far as human populations were concerned, the command to be fruitful and multiply was fulfilled as early as the era described in Genesis 10:1-32, which reports how Noah's sons' families "spread abroad on the earth after the flood."

Humans were not the only beings instructed to "be fruitful and multiply" in primordial times. All kinds of sea creatures and birds had been so commanded the "day" they were created. (Gen 1:20-22). Sea creatures were not again ordered to "be fruitful and multiply" after the flood. The flood, of course, would not have affected sea species. $^{16}$ But after the flood, as the story is told, God declared that all creatures of the land and air-"all flesh-birds and animals and every creeping thing that creeps on the earth"-were to "breed abundantly" and "be fruitful and multiply upon the earth." (8:17). All these postdiluvian families of air-breathing creatures were meant to enjoy life and space in the world, and perpetuate their respective species-implicitly so long as the earth endured. ${ }^{17}$ None of these texts calls upon humans or other species to keep on being fruitful and multiplying up to the brink of ecological catastrophe, whether in the form of Malthusian over-crowding or population collapse. From the standpoint of the biblical writers who set down these "commandments," they, too, already had been fulfilled. By the time of the Psalmist, all creatures had been fruitful and multiplied. ${ }^{18}$

Before the flood, humans along with birds and all other land creatures, were vegetarians. (Gen 1:29-30). After the flood, the era

16. "Everything on the dry land in whose nostrils was the breath of life died." Gen 7:22.

17. That implication is made explicit in the covenant God made with all living beings in the following chapter (Genesis nine). See part III.

18. See, for example, Psalms 104:24: "O YHWH, how manifold are thy works! ... [T] earth is full of thy creatures." Psalm 104 and P tradition were set down at approximately the same time. See also Sir. 16:29-30. 
of human vegetarianism was over. The initial harmony between humans and other creatures that had obtained in the Garden of Eden and on board the ark, came to an end. Now other creaturesthe beasts of the earth, birds of the air, creeping things on the ground, and fish of the sea-had reason to fear and dread humankind. (9:1-3). Some humans would become hunters ${ }^{19}$ and fishers. $^{20}$

Nevertheless, human beings were to respect the "life" of all land animals and birds killed for food. The "life" of each creature was thought to be contained in its blood. (Gen 9:4). Thus humans might eat the flesh of other creatures but not their blood. (9:3-4). The context suggests that this consideration was to apply to fish as well as to other life forms. This limitation expresses a kind of reverence for life. ${ }^{21}$ Other creatures might be killed and eaten as food, but their "life" must not be destroyed. ${ }^{2}$ It may have been understood that the creature's life/blood would be preserved by being returned to the ground. Similar provisions appear in later Israelite or Jewish laws governing the slaughter of animals for food. ${ }^{23}$ Unlike these later laws, which were for the guidance only of Israel or the Jewish people, the Genesis 9:4 prohibition against eating flesh with its life or blood was intended for all the descendants of Noah, that is, all humankind, whatever their nationality. ${ }^{24}$ This understanding may have been in the minds of those early Jewish-Christian leaders who agreed that gentile converts to Christianity were not to eat blood or the meat of animals that had been strangled. ${ }^{25}$

\section{THE P COVENANT "WITH EVERY LIVING CREATURE": GENESIS 9:8-17.}

Before the great flood, according to $\mathrm{P}$ tradition, God instructed Noah to build a large ship ${ }^{26}$ and bring on board:

19. See Gen 10:8-9; also 25:27; 27:3-4, 30-33.

20. Gen 9:2. Strangely little is said about fishing or eating fish in the Jewish scriptures or Old Testament. The only explicit instances are Num 11:5; Ezek 47:10; and Tobit 6:1-5. See also Neh 13:16.

21. See note $\mathbf{1 1 5}$ and accompanying text.

22. Clearly more is involved here than a mere "visceral prohibition against the consumption of blood." Ismar Schorsch, Learning to Live with Less, in Rockefeller \& Elder, eds, Spirit and Nature at 31 (cited in note 10).

23. See Lev 17:10-14; Deut 12:20-27.

24. According to Gen 10:1-32, all later humankind descended from Noah.

25. Acts 15:19, 28-29.

26. The vessel was said to be 450 feet long, 75 feet wide, and 45 feet high, with three decks. 
[o]f the birds according to their kinds, and of the animals according to their kinds, of every creeping thing of the ground according to its kind, two of every sort... [in order] to keep them alive. ${ }^{27}$

This was to be done so that all these species might be spared, and later emerge from the ark in order "that they might breed abundantly upon the earth, and be fruitful and multiply upon the earth." (Gen 8:17). ${ }^{28}$ In effect, Noah's ark project was undertaken in order to preserve biodiversity. ${ }^{29}$

After the flood, Noah offers YHWH sacrifices "of every clean animal and of every clean bird." (Gen 8:20). In the earlier "J" accoun ${ }^{30}$, YHWH had instructed Noah to take seven pairs of all clean animals and seven pairs of birds "to keep their kind alive upon the face of the earth" in the era that would follow the flood. (7:1-3). Thus these species would not become endangered when Noah later sacrificed some of each. YHWH then declares that He will never again curse the ground because of man, nor ever again destroy every living creature. (8:21). This $\mathrm{J}$ tradition is in the form of a promise, but also is parallel in substance to the $\mathrm{P}$ covenant that follows. This $\mathrm{J}$ promise (or covenant) is unqualified: YHWH will never again destroy every living creature, and so long as earth remains, the cycles

Gen 6:15-16.

27. Gen 6:20. See also Gen 7:14-15.

28. Holmes Rolston refers to Noah's ark project as the first "Endangered Species Act." Rolston, Environmental Ethics at 94 (cited in note 10). Critics who consider texts such as Gen 1:26-28 dispositive as to the biblical viewpoint in regard to human relations with other creatures typically ignore Noah's ark project. See, for example, Peter Singer, Animal Liberation: A New Ethics for our Treatment of Animals $193-95$ (Random House, 1975). Such critics generally make no mention of the P covenant with every living creature (Gen 9:8-17) either.

29. Albert Gore, Earth in the Balance: Ecology and the Human Spirit 244-45 (Plume, 1993). Contrast Bill Moyers, Genesis: A Living Conversation 111-53 (1996). Moyers and his conversationalists make no mention of Noah's role in preserving all kinds of air-breathing species or of the the covenant with all living beings for all generations. But see Bruce Babbitt, Between the Flood and the Rainbow: Our Covenant to Protect the Whole Creation, 2 Animal L, 5 (1996): "God did not specify that Noah should limit [passengers on] the ark to two charismatic species, two good for hunting, two species that might provide some cure down the road, and two that might draw crowds at the city zoo. He specifies the whole creation." Id. (emphasis in original).

30. "J" is the symbol commonly used by biblical scholars to designate texts thought to derive from the "Yahwist" collector(s) and editor(s) of earlier traditions that appear in most of the biblical "books" from Genesis to 1 Kings. The symbol derives from the first letter of the transliterated divine name Jahveh (German) [Jehovah, Yahweh, YHWH in English] typically used in these texts as early as Genesis, chapter two. It is commonly thought that the "J" texts were collected and edited in the $10^{\text {th }}$ century B.C.E. in Judah either during the time of Solomon, or a few decades afterwards. On major themes in J tradition, see Steck World and Environment at 6478 (cited in note 3 ). 
of nature will continue. (8:22). ${ }^{31}$ The $P$ narrative that follows in Genesis nine then reports God's resolution never again to destroy "all flesh" or the earth by flood waters. $(9: 11,15)$.

In this context, $\mathrm{P}$ tradition refers five times to the covenant which God made not only with humans, but also with all kinds of creatures that, as the story was told, had been with Noah on the ark. These included all life forms then known (other than sea creatures, which would not have needed the ark in order to survive the great flood). ${ }^{33}$ This was the first and most explicitly inclusive of all biblical covenants. It was first in the sense that in the completed biblical narrative, it comes before all subsequent accounts of covenants made with Abraham and his descendants. ${ }^{34}$

The terms of these several references to this covenant leave no doubt as to its inclusiveness. It was made "with every living creature ..., the birds, the cattle, and every beast of the earth ..., as many as came out of the ark." (Gen 9:9-10). According to Genesis 9:12, God made this covenant between himself and Noah and his sons "and every living creature ... for all future generations." In Genesis 9:15, God speaks of "my covenant which is between me and you and every living creature of all flesh." Genesis 9:16 refers to "the everlasting covenant between God and every living creature of all flesh that is upon the earth."35 And finally in Genesis 9:17, God again points to "the covenant which I have established between me and all flesh that is upon the earth."

These repetitions of this covenant and its terms clearly were intended to emphasize its inclusion not only of humans but also of "every living creature of all flesh." ${ }^{\text {"I6 }}$ In each of the five formulations just summarized, however, the covenant is said to be made by God with Noah and every living creature. The importance of each living

31. This covenant is the basis for the later prophetic affirmation that YHWH's "covenant of peace" would never "be removed." Isaiah 54:9-10.

32. See generally, Anderson, From Creation to New Creation at 156-64 (cited in note 3), and Granberg-Michaelson, $A$ Worldly Spirituality at 73-90 (cited in note 10).

33. See Gen 7:22.

34. The other main biblical covenants include those described in Gen 12:1-3; 15:1-21; 17:114; 26:1-5; 28:13-15; Exod 19:5-6 (Exod 20:1-23:33); and Exod 34:10-27. On biblical covenants, see generally, Simkins Creator and Creation at 152-72 (cited in note 3).

35. Compare Isaiah 24:5, ("the everlasting covenant"), and Psalm 145:13 ("everlasting kingdom").

36. Contrast Simkins Creator and Creation at 154-56 (cited in note 3), who characterizes the $P$ covenant as God's covenant with all creation. Jay Byrd McDaniel reflects on contemporary implications of this $P$ covenant in his chapter, $A$ God Who Loves Animals, in Charles Pinches \& Jay Byrd McDaniel, eds., Good News for Animals? 86-91 (1993). 
creature is thereby emphasized. ${ }^{37}$ This covenant implies that all life forms were meant to have their places or spaces upon the earth. ${ }^{38}$ The time-frame was not limited to the period immediately after the flood; instead, it was to continue in effect "for all future generations."

It is striking that this covenant did not call on humans or other creatures to do anything in particular. Instead, in each of its five formulations, it was unconditional. Implicitly, humans and other creatures were merely expected to continue in existence, from generation to generation, as the kinds of beings they had been created to be. All these, and sea creatures too, God had pronounced "good," indeed, "very good," according to the P creation narrative. (Gen 1:20-31). The clear implication of this covenant is that all life forms were valued by God and that human participants in the covenant should therefore affirm their value as well. Thus this covenant could be seen as the foundation for later biblical laws mandating humans' concern for animal well-being.

Clearly this covenant was not anthropocentric. ${ }^{40}$ It was made with and for the benefit of all kinds of living creatures. Nor did it suggest any warrant for humans to exploit or destroy other species." This covenant was intended to remain operative throughout history, during which God would continue to care for all living creatures. The rainbow was to be the sign of this covenant. (Gen 9:12-17). Later traditions likewise affirm God's care for all kinds of living

37. In Gen 9:13, the covenant is said to have been made between God and "the earth." It is unclear whether, in this context, "the earth" itself is meant, or whether "the earth" stands for the fuller expression, "every living creature of all flesh that is upon the earth" as in Gen 9:16 and 17.

38. "The covenant [Gen 9:17] ... suggests that the Creator's purpose is to provide living space for all organisms, so that they may share the earth together." Nash, Loving Nature at 101 (cited in note 7).

39. As to biblical creation traditions, see Ian Barbour, I Religion in an Age of Science 130 35 (Harper and Row, 1990).

40. Babbitt, 2 Animal L at 5 (cited in note 30), (regarding the rainbow, the sign of the covenant): "We are thus instructed that this everlasting covenant was made to protect the whole of creation, not for the exclusive use and disposition of mankind, but for the purposes of the Creator." Several other commentators have also demonstrated that biblical faith generally is not anthropocentric. See, for example, Dianne Bergant, Is the Biblical Worldview Anthropocentric? 4 New Theology Rev no. 2:5-14 (1991); John Cobb, Jr., Sustainability, Economics, Ecology, and Justice 92-93 (Orbis Books, 1992). See also, Barlow, 23 BC Env Affairs L Rev at 783 (cited in note 1). "In short, the [biblical] environmental narrative is neither biocentric nor anthropocentric; it is theocentric." Id.

41. Nothing in this covenant suggests that humans were to have dominion over other creatures. God, who initiated this covenant, was the one who had dominion. See note 15 and accompanying text. 
creatures. ${ }^{42}$ Other biblical texts likewise anticipate that at the end of history, in the future or Messianic age, YHWH would make operative a new covenant under which all creatures would dwell together in peace. ${ }^{43}$

\section{Biblical Law Codes: AN OVERVIEW}

A law code may be defined as a collection of laws in effect at a given time in a particular society. Afterwards, typically, new laws are promulgated (or court decisions add new "constructions" or interpretations), while other laws may be formally repealed or tacitly abandoned. So in most societies, new law codes are prepared from time to time to replace those that have become outmoded. It is not surprising to find several law codes embedded in biblical tradition which draws upon and recounts several centuries of Israelite, Judahite, and Jewish experience. As the biblical codes are presented, however, all purport to be versions of the laws given by God (or YHWH) to Moses at Mt. Sinai (or Mt. Horeb), and then transmitted by Moses to Israel during the several decades while the Israelites were wandering in the Sinai peninsula after leaving Egypt but before entering into the land of Canaan.

Probably the earliest of these collections is the so-called "Ritual Decalogue" (RD) contained in Exodus 34:11-28. Several of its provisions appear in later codes. The first comprehensive code is the Covenant Code (CC), also known as the Book of the Covenant, found in Exodus 20:1-23:33, which may date from the $12^{\text {th }}$ to the $11^{\text {th }}$ centuries B.C.E. Many of the laws set out in the Covenant Code were incorporated later into the Deuteronomic Code (D), presented in Deuteronomy 5:1-21 and 12:1-26:15. The Deuteronomic Code may have been written down only a century or so after the Covenant Code. However, a number of the provisions found in Deuteronomy 12-19 probably were added subsequently in connection with the Deuteronomic reform, a major institutional innovation carried out late in the seventh century B.C.E. This innovation established Jerusalem as the only place where YHWH (or God) could be worshiped with sacrificial offerings, and called for closing all other shrines. $^{44}$ Deuteronomy 6-11 consists of a series of exhortations,

42. See, for example, Psalms 36:5-6; 104:10-26; 136:25; 145:8-9, 14-17; Wisdom 11:26; Sirach 18:13.

43. See section $X$ of this article.

44. See part V.B.2. of this article. 
some probably of ancient origin, as to the critical importance of keeping these laws.

The next codification dates from the middle of the seventh century B.C.E. This is the "Holiness Code" $(\mathrm{H})$ found in Leviticus 18-26. ${ }^{45}$ The Holiness Code does not require that sacrificial worship take place only in Jerusalem; and it twice refers to plural "sanctuaries." (Lev 21:23; 26:31). It therefore may be dated prior to the Deuteronomic reform. Parts of it, however, may have been edited or revised by $P$ or Priestly editors who refer, twice, to the "tent of meeting," considered a portable prototype of the later Jerusalem temple. The authors or editors of $\mathrm{H}$ also appear to distinguish priests, the "sons of Aaron," from Levites, another typical P hallmark. Ritual purity is a leading concern in the Holiness Code.

The last, and most recent of the law codes commonly is characterized as the Priestly Code (or PC). It probably was set down during the late sixth or fifth century B.C.E. under the auspices of priests then functioning at the Jerusalem temple. It is so designated because its provisions refer, typically, to sacrificial offerings and other procedures and ceremonies in which priests figure prominently. It is the most extensive of the law codes, and includes all laws contained in Exodus 24:1 through Numbers 36:13, except for those found in $\mathrm{RD}$ and $\mathrm{H}^{47}$

Laws relating to reverence for life and/or environmental ethics are found in all of these biblical codes, including the Ritual Decalogue. Occasionally it is possible to trace certain developments or changes in specific laws as one moves from earlier to later codes.

\section{SACRIFICIAL LAWS-ANIMAL SACRIFICES}

It may seem odd to include texts calling for animal sacrifices in a study of reverence for life and environmental ethics in biblical law. ${ }^{48}$ Several considerations justify this inclusion. For one thing, such laws constitute a substantial portion of biblical law, and therefore should

45. Interpreters often include Leviticus 17 in the Holiness Code. Because of its affinity to characteristic Priestly motifs, however, that chapter is considered part of the Priestly Code in this article.

46. Lev 19:21;24:14.

47. In this article, we also consider Exodus 13:1-16 part of the PC.

48. Biblical commentators typically pass over such texts in silence, while studies of biblical faith and environmental ethics hardly ever mention them at all. 
be considered, whatever attitudes they may reveal toward the animals that were to be sacrificed. Most significant, is the understanding these laws express in regard to the importance of animal life. Many of the laws affirm that animals belong to and are given by God, who values them highly. That animals might be sacrificed instead of humans likewise indicates a sense of their worth, as if somehow equivalent to that of human life. Respect or reverence for the life of sacrificed (or slaughtered) animals comes to expression particularly in laws governing disposal of their blood.

\section{A. Consecration of the First-Born: One of the Earliest Laws}

The demand that first-born sons and domestic animals be sacrificed or consecrated to God (or YHWH) appears in all of the codes except $\mathrm{H}$. Several of the laws provide for redeeming firstborns. In some instances, first-born sons may be redeemed by offering an animal instead.

\section{The Ritual Decalogue}

Exodus 34:19-20, found in the early Ritual Decalogue, states the rationale for offering first-born sons and animals: "All that opens the womb is mine," says YHWH ${ }^{49}$ This text also provides for redeeming both first-born sons and first-born asses' colts. How first-born sons were to be redeemed is not stated. First-born asses' colts might be "redeemed" or spared by offering a lamb instead. It is not said that the lamb must also be a firstling. The ass was not considered a "clean" animal-that is, one that Israelites or Jews might eat. If the owner chose not to redeem a first-born ass's colt, he was to break its neck. The underlying thought seems to have been that because firstborn domestic animals come from, and so belong to YHWH, they should be returned to Him either in the form of a sacrificial offering in the case of a "clean" animal, or if an "unclean" animal, by killing it, unless it was redeemed by offering another animal instead.

After a first-born animal had been sacrificed or killed, and YHWH thereby given back his own, animals borne later by the same mother could be kept and used by their human owners. Except, of course, that when this next generation of animals gave birth for the

49. It was YHWH or God, of course, who created all life forms in the first place. Gen 1:11-27 [P]; Gen 2:6-23 [ग]. 
first time, the newborns would again be YHWH's, and should be given back to Him. Thus any sense that humans owned their domestic animals was strictly qualified by recognition that $\mathrm{YHWH}$ owned all first-borns, generation after generation.

\section{The Covenant Code}

Exodus 22:29b-30, found in the Covenant Code, provided that first-born sons, as well as first-born oxen and sheep, should be "given" to God. The text does not state that first-born sons were to be sacrificed to God; but the context implies that requirement. Here there is no provision as to whether or how such sons might be redeemed. The story of Abraham's substitution of a ram for his firstborn, Isaac, may have been told in order to allow for, or perhaps require, the sacrifice of an animal instead of the first-born son. (Gen 22:1-14). ${ }^{\text {so }}$ The Genesis story does not require that the substituted sacrificial ram also be a first-born. No biblical narrative reports that any other parents understood that they were obliged to sacrifice firstborn sons. ${ }^{\text {sl }}$

The requirement to sacrifice first-born sons and first-born oxen and sheep alike, implies that both human and these animal offspring were understood to have their common origin and value in relation to God who not only created the first humans and animals, long ago, but continues to give fertility and procreation to each species, from generation to generation.

Exodus 22:29-30 evidently reveals a kind of humane concern: new first-born bull calves and male lambs were to remain with their mothers seven days before being sacrificed on the eighth day. ${ }^{52}$ Thus both mother and new-born would have those few days together. Similar kinds of sensitivity to the interests or feelings of young

50. Both the CC and Genesis 22 probably were included in $\mathrm{E}$ or Northern tradition which was collected and written down between 950 and 850 B.C.E. In that tradition, the Genesis 22 story would have functioned as case law (or common law), construing the sacrificial ordinance set out in Exodus 22:29-30.

51. But see Judges 11:30-40 (because of his tragic vow, Jephthah sacrificed his daughter after defeating Ammonite invaders); 1 Sam 1:9-28 (Hannah, who had been infertile, true to her vow, gave her first-born son, Samuel, to the priest Eli as his assistant); and a few traditions where the practice was condemned (1 Kings 16:33-34; 2 Kings 16:2-4; Ezek 20:25-26; and Micah 6:6-8).

52. Later Priestly law provided that all male infants descended from Abraham were to be circumcised on the eighth day (Gen 17:9-14). It might be conjectured that circumcision on the eighth day was a ritual vestige of the ancient law requiring sacrifice of first-born male sons on the eighth day. 
animals and their mothers may also be seen in other biblical laws, for example, Lev 22:27, in the Holiness Code, which applies the sevenday requirement to all new-born bull calves, lambs, and kids. ${ }^{53}$

\section{Deuteronomic Reform Provisions}

Deuteronomy 15:19-23. The Covenant Code provided for the sacrifice of first-born male oxen and sheep. ${ }^{54}$ It did not distinguish between sacrifices offered at a central sanctuary and those conducted locally, nearer to home. After the Deuteronomic reform, however, sacrificial offerings were to be made only at that one "place."ss Deuteronomy 15 appears to be cognizant of that new requirement, and probably was part of the reform program found in Deuteronomy 12-19. According to Deuteronomy 15:19-20, not only all first-born male sheep and oxen, but also first-born males from other "herd[s]" and "flock[s]" were to be sacrificed and eaten "before YHWH" at the central shrine. The Exodus law does not distinguish between blemished and unblemished animals; but the Deuteronomic version provides that blemished first-borns not be sacrificed to YHWH. ${ }^{56}$ Blemished, first-borns, however, might be slaughtered locally and eaten (15:21-22); but as with the secular slaughter provision at Deuteronomy 12:15-28, the animals' blood must not be consumed. Instead, their blood must be poured out on the ground (15:23), presumably, in order that the animals' life may be preserved by returning to its source.

\section{The Priestly Code}

The Priestly Code is very largely concerned with sacrificial offerings. A number of PC laws relate to first-borns, both human and animal. Within the corpus of $\mathrm{P}$ laws, we see a number of additions and variations that, one way or another, exempt Israelite first-borns, and provide alternatives to the sacrifice of first-born animals.

Exodus 13:1-2 and 11-15 say that the first-born males of both

53. See part VI.

54. Exod 22:29b-30.

55. See part V.B.2. of this article.

56. Compare Deut 17:1, to the same effect.

57. See Deut 12:15-16, 20-25. 
Israelites and their cattle were to be "consecrated" to YHWH..$^{58}$ Verses 1-2 read:

YHWH said to Moses, "Consecrate to me all the first-born; whatever is the first to open the womb among the people of Israel, both of man and beast, is mine.

"Consecrate" may mean to sacrifice, or it may mean to set aside as holy. The language is species- and gender-inclusive: "all the firstborn; whatever is the first to open the womb." That would seem to include all kinds of animals, but probably only domestic animals were intended-both male and female. Implicitly, daughters were included as well as sons. The original sense seems to have been that because YHWH brought about conception and birth, the first-born was to be offered back to Him in return as a gift of thanksgiving or gratitude. The biblical editors or narrators probably placed the present text, chapter 13, here because of its focus upon the first-born of the Egyptians and their cattle and upon YHWH's sparing the firstborn Israelites in Exodus 11-12.9 Exodus 13:1-2 and 11-15 are set in the context of the Israelites' last moments in Egypt, before crossing the Red Sea, rather than-as might be expected-among the laws given by YHWH to Moses on Mt. Sinai. Exodus 13:11-12a likewise uses inclusive language: "You shall set apart to YHWH all that first opens the womb." Verse $12 b$, however, refers only to "firstlings of your cattle that are males." Verse 13 then provides for the redemption of first-born sons and firstlings of asses. Like Exodus 34:19-20, from which it appears to derive, this text does not say how first-born sons were to be redeemed. As in Exodus 34:19-20, firstling asses were to be redeemed by offering a lamb; but if not redeemed, the young ass's neck was to be broken. (13:13). Another PC law, however, Numbers 18:14-20, provides that the firstlings of unclean animals were to be redeemed by payment of five shekels, while firstborn cows, sheep and goats were to be "holy," that is, after they had been slaughtered, the meat was to be given to the priests and their families "as a perpetual due."

Numbers 3:11-13 and 8:16-19: Levites instead of first-born Israelites. These verses add that YHWH took the Levites or tribe of Levi instead of the first-born among the people of Israel generally, and consecrated them to be permanent assistants to the sons of

58. See, also Num 18:14-19; cf. Exod 22:29b-30.

59. Exod 13:14-16 makes this connection explicitly. 
Aaron, i.e., in $\mathrm{P}$ tradition, the priests. ${ }^{60}$ It may be that this provision was modeled on the story in 1 Samuel $1: 1-2: 21 .^{61}$ These texts from Numbers provide a different explanation for Israel's abandonment of the practice of offering first-born sons (and perhaps also daughters). ${ }^{6}$

Numbers 3:40-45: First-born cattle of the Levites instead. Numbers 3:11-13, 41a, and 45a also add that YHWH declared to Moses that $\mathrm{He}$ would accept the first-born cattle of the Levites "instead of all the firstlings among the cattle of the people of Israel." $(3: 41,45){ }^{63}$ The text does not indicate whether this arrangement was to obtain only during the time the Israelites were in the wilderness, or whether it was to be the law also for future generations. According to Numbers 31:25-47, the Levites were later given onefiftieth of all the cattle taken as booty from the Midianites. ${ }^{64}$ Subsequent tradition in Numbers calls for enormous numbers of sacrificial offerings; but refers to offerings of first-born cattle in only one text. (18:15-18). No other biblical tradition dating after $c a .400$ B.C.E. refers to first-born offerings of any sort. Possibly Numbers 3:40-45 represents a shift in priestly circles away from the idea that God required the sacrifice of the first-born cattle of all Israelites. Those of the Levites would be enough.

Numbers 18:8-19. Here P tradition provides that substantial portions of sacrificial offerings both then and in future generations would belong to the priests (Aaron and his sons) "as a perpetual due." (18:8). Again we see provisions for "devoting," that is, sacrificing "everything that opens the womb of all flesh, whether man or beast;" however, only first-born humans and unclean beasts are to be redeemed. (18:15). These are to be redeemed "at a month old," and the redemption price is set at five shekels of silver-evidently the same for both first-born humans and first-born of unclean beasts. (18:16). First-born cows, sheep, and goats are not to be redeemed, but rather sacrificed, with the priests and their families receiving all edible portions. (18:17). How these provisions in Numbers 18 are to

60. See also Num 3:41a, 45a; $18: 6$.

61. That story tells how Hannah, out of gratitude to YHWH for granting her prayer for a son, "loaned" this son, Samuel, to YHWH by giving him as an assistant to the priest Eli.

62. Compare Gen 22:1-14.

63. Here, as in most other biblical texts, "cattle" probably refers to all kinds of domestic or farm animals.

64. Perhaps the writer of Numbers 3 was thinking of these cattle as the source of first-born sacrificial offerings. See also Num 35:1-8 and Joshua 21:1-42 which provide pasture land for the Levites. 
be read in the light of the laws found in Numbers 3:41 and 45 is not clear. Numbers 18 makes no mention of the Levites' cattle.

\section{B. Other Types of Laws Requiring Animal Sacrifices}

Laws requiring the sacrifice of first-born domestic animals are found in the two earliest law codes: RD and CC. Similar laws have been traced in later codifications, notably Deuteronomy $15,{ }^{65}$ and the Priestly Code. Surprisingly few other provisions regarding animal sacrifices are found in the earlier law codes. The only other provisions in $\mathrm{RD}$ are in Exodus $34: 25^{66}$ which are repeated with slight variation in the CC, Exodus 23:18. ${ }^{67}$ The only other reference to animal sacrifice in the CC is at Exodus 20:24, describing the altar to be made for sacrificing burnt and peace offerings involving sheep and oxen. The earlier portions of the Deuteronomic Code (Deut 5, $20-25)$ contain no laws concerning animal sacrifices. ${ }^{68}$ Even the relatively recent $\mathrm{H}$ ( $\operatorname{Lev} 18-26)$ includes only a few provisions regarding animal sacrifices: $(19: 5-8 ; 22: 17-29 ; 23: 12-20$; and possibly 23:36-38). And Deuteronomy 12-19, which provides that sacrifices be offered only at the Temple in Jerusalem, contains only a few specific provisions regarding animal sacrifices besides those relating to first-borns (15:19-23); 16:2-7 (the "passover sacrifice"); 17:1 (barring sacrifice of blemished oxen or sheep); and 18:1-3 (portions of sacrificed animals constituting "the priests' due from the people").

Laws relating to blemished animal offerings will be reviewed next. Then follows a brief description of the new laws relating to sacrifices introduced in connection with the Deuteronomic Reform of 622 B.C.E. Finally, the more extensive sacrificial laws found in the Priestly Code will be considered.

\section{Only Unblemished Animals}

Leviticus 22:17-25. This text is part of $\mathrm{H}$, but may reflect some later $\mathbf{P}$ or priestly concerns. The requirement that sacrificial animals-namely, bulls, sheep, and goats-be male and without

65. See part V.B.2.

66. "You shall not offer the blood of my sacrifice with the leaven; neither shall the sacrifice of the feast of passover be left until morning." Exodus 34:25. The other sacrificial law in $R D$ is given in Exod 34:19-20. See section V.A..1.

67. "You shall not offer the blood of my sacrifice with leavened bread, or let the fat of my feast remain until morning."

68. But see Deut 21:1-9, described in part V.B.3.b. of this article. 
blemish here applies only to votive or freewill offerings. (22:18-19). Animals presented as peace, votive, or freewill offerings must be without any blemish. (22:21). However, bulls or lambs with a minor deformity ("a part too long or too short") might be presented for freewill, but not for votive offerings. (22:23). Any animals that are blind, disabled, mutilated, or afflicted with discharges, itches or scabs may not be given for burnt offerings. (22:22). The post-exilic prophet Malachi likewise condemned such offerings. (Mal 1:6-14). The concern seems to have been that YHWH deserved only the best of the kinds of animals that might be sacrificed.

Deuteronomy 17:1. This text provides that blemished oxen and sheep are not to be sacrificed to YHWH on any occasion. The Holiness Code contains a provision to similar effect. (Lev 22:17-25). The Leviticus text specifies a variety of possible blemishes, and applies to several kinds of animals, but allows sacrifice of bulls or lambs which have "a part too long or too short" as freewill offerings. The Deuteronomic version refers only to blemished oxen and sheep, and states simply that offering such animals in sacrifice "is an abomination to YHWH." ${ }^{, 69}$ Very likely, Deuteronomy 17:1 was part of the Deuteronomic Reform program.

2. The Deuteronomic Reform: Worship in One Place; Secular Slaughter, and Respect for Sacrificial Animals' Life (Blood)

Nothing in the CC, J, E, or other early biblical laws or narratives indicates that Israelites originally were required to worship in only one place. Canaanites and other indigenous peoples had worshiped their gods at numerous local shrines. So had the Israelites, it seems, until the latter part of the seventh century B.C.E., when D was amended or expanded (particularly in Deuteronomy 12-19), so as to require that they offer sacrifices now only at the one "place.",

\section{a. Deuteronomy 12:1-13:1: Sacrificial Worship Now Only in the One Place}

Deuteronomy 12:5-7 sets forth what appears to have been a new

69. Cf., Mal 1:8-14.

70. Major shrines reportedly used in earlier times include Bethel, Gilgal, Hebron, Shechem, and Shiloh. See, for example, Joshua 8:30-35;24:25-26; 1 Sam 1:24; 9:11-14. On the Deuteronomic Reform program, see generally Gerhard von Rad, Deuteronomy: $A$ Commentary 87-94 (Westminster Press, 1966). 
requirement: the people of Israel (or Judah) were now told that they might offer animal sacrifices only at "the place which YHWH your God will choose out of all your tribes to put his name and make his habitation there." Contemporary readers, of course, would have recognized this place as the temple in Jerusalem. ${ }^{71}$ This, and related commandments, were probably part of what has come to be called the Deuteronomic Reform of ca. 622 B.C.E. The reform was intended to reduce rural Israelites' temptation to worship the other gods associated with the old Canaanite cult shrines. As if to drive home this new understanding, the requirement that sacrifices be presented only in the one place is repeated several times in chapter $12 .^{72}$

In earlier laws set out in the Covenant and Holiness codes, there was no requirement that Passover, the feast of weeks, or the feast of booths be observed only in "the one place." Deuteronomy 16:1-17, however, all three of these major festivals were to be observed there and there only, at least so far as sacrificial offerings are concerned. ${ }^{74}$

A corollary to worship in only the one place was the requirement that the Israelites destroy the old shrines where they and their neighbors had "served their gods, upon the high mountains and upon the hills and under every green tree." (Deut 12:2). Therefore, the Israelites were to "tear down" the altars and images representing or associated with these gods. (12:3). ${ }^{75}$ Worship of these other gods was forbidden not only because, according to Israelite belief, YHWH alone was the god who created everything and continues to give of creation's bounty to his people; but also because worshipers of other gods engaged in "abominable" and cruel practices. $^{76}$ Other texts also indicate that from the standpoint of Israelite faith, worship of Canaanite and other foreign deities often

71. Israelites did not succeed in occupying Jerusalem until the time of David, some 200 years after their settlement or conquest of the rest of the land; and the temple was not built until the time of Solomon, ca. 950 B.C.E., nearly 300 years, according to tradition, after YHWH gave Moses "the law" on Mt. Sinai.

72. Deut 12:5-7, 11-14, 17-19, 26-28. This "one place," the Jerusalem Temple, was also regarded as a bird sanctuary in Psalm 84:1-3. See Theodor H. Gaster, Myth, Legend, and Custom in the Old Testament 765-66 (1969).

73. See Exod 23:14-17; Lev 23:4-21, 33-34.

74. See Deut 16:2, 5-6, 7, 10-11, 15, 16 .

75. Compare Exod 34:13.

76. "For every abominable thing which YHWH hates they have done for their gods; for they even burn their sons and their daughters in the fire to their gods." (Deut 12:31). 
involved depraved practices-which earlier Israelites, too, sometimes had followed."

\section{b. Deuteronomy 12:15-16, 20-25: Secular Slaughter and Reverence for Life}

It appears that in earlier biblical times, whenever a domestic animal was killed for food, the animal, or part of it, was to be offered to YHWH, usually at one of the nearby cult shrines. Conversely, when an animal or agricultural sacrifice was made to YHWH, those who made the sacrifice would eat part of it-except in the case of burnt offerings. ${ }^{78}$ Now that the old cult shrines were to be closed as part of the Deuteronomic Reform, these new provisions in Deuteronomy 12 allowed Israelites to slaughter their animals for food without religious ceremony. ${ }^{79}$ But those who ate the flesh of such animals must not also eat their blood, "for the blood is the life, and you shall not eat the life with the flesh." (12:23). Instead, the animal's blood must be poured "out upon the earth like water." $(12: 24 ; c f .12: 27){ }^{80}$ We see this kind of provision in later $\mathrm{P}$ narratives and laws. ${ }^{81}$ The Deuteronomic laws here may reflect earlier beliefs and practices. Under the law of Deuteronomy 12, even though animals killed for food were no longer offered to YHWH, its provisions show a sensitivity to and respect for the life of the animals. Their life was to be returned to the ground, from which, ultimatelyaccording to the old $\mathrm{J}$ creation narrative-all such creatures originally had been formed. (Gen 2:18-19).

\section{Additional Sacrificial Offerings in the Priestly Code}

Long ago, Julius Wellhausen, pointed out that several types of sacrificial offerings appear for the first time in the PC. $^{82}$ And as has been noted above, relatively few kinds of sacrificial laws are to be

77. See, for example, Lev 18:21; Deut 18:10-12; 23:17-18; Judges 11:30-31; 1 Kings 16:34; 2 Kings 3:27; 16:3;21:6; Jer 7:31; 19:5; 32:35; Ezek 16:20-21.

78. See, for example, Exod 22:14-17; Lev 23:4-44; 1 Sam 9:11-13, 22-24; 14:31-35.

79. Deuteronomy 12.21 provides that animals may be slaughtered without religious ceremony only if the trip to Jerusalem is "too far." Deuteronomy 12:15, however, gives blanket permission for secular slaughter without that limitation.

80. Presumably the same procedures were to apply when wild animals were killed for food. See Deut 12:15, 22; compare Lev 17:13-14.

81. See Gen 9:3-4; Lev 17:10-11.

82. Julius Wellhausen, Prolegomena to the History of Ancient Israel 1-82 (Peter Smith, 1973). 
found in the earlier codes: $\mathrm{RD}, \mathrm{CC}, \mathrm{D}$, and $\mathrm{H}^{83}$ Several of these new PClaws are now to be described.

\section{a. Sin Offerings and Ordination of Priests}

Exodus 24-40 consists largely of $\mathrm{P}$ laws and narratives regarding the tent of meeting or tabernacle, along with descriptions of its elaborate furnishings. The tent or tabernacle supposedly served as the sole place of worship during the period of Israel's sojourn in the wilderness. ${ }^{84}$ In these chapters, there are surprisingly few laws regarding sacrificial offerings as such.

The main section devoted to sacrificial laws is Exodus 29. A bull and two rams were to be sacrificed in connection with the consecration or ordination of Aaron's sons as priests. A bull was to be offered "as a sin offering for atonement" each of the seven days the ordination ceremony continued. (29:1-37). Exodus verses 15-33 describes how the rams were to be killed and their blood and body parts used in preparing burnt offerings and food for the priests. Moreover, two lambs were to be offered every day, generation after generation. (29:38-42). ${ }^{\text {s5 }}$ Numerous similar and related ordinances are to be found in P strata in Leviticus and Numbers. Generally in these $P$ traditions, it appears to be assumed that God required such sacrifices not so much because $\mathrm{He}$ is to be acknowledged as the source of all life, but because $\mathrm{He}$ delighted in such offerings. Implicitly, when God was pleased by such offerings, He would overlook the priests' and other Israelites' shortcomings. It is questionable whether all the kinds and numbers of animal sacrifice described in these chapters were actually carried out during the period of Israel's sojourn in the wilderness (a time of scarcity and bare subsistence) ${ }^{86}$ or prior to the construction of Solomon's temple.

\section{b. Sacrifices to Heal or Purify}

Leviticus 14:1-54: Curing leprosy. Various animal and bird

83. See part V.B., and text accompanying notes $66-69$.

84. The tent of meeting or tabernacle and its elaborate furnishings probably represented a glorified version of what had been Solomon's temple as remembered or imagined and projected back into the wilderness period by $P$ writers in later times.

85. See also Exod 30:10, referring to "the blood of the sin offering of atonement."

86. See, for example, Exod 16:1-36; Num 11:4-15.

87. See 1 Kings 5-8. 
sacrifices are described here in connection with attempts to cure leprosy. Reference to guilt and sin offerings (for example, 14:12-14, 21-22) suggest that a person with this disease was thought to have sinned. The offerings then could make atonement. (14:30-31). Some of the procedures also seem to suggest that the blood of sacrificial birds or animals could have a cleansing or therapeutic effect. (for example, 14:6-7, 52). ${ }^{88}$ Such sacrifices also may have been thought of as thank offerings presented by those who were being, or had been cured.

Numbers 19:1-22: Ashes of a red heifer. This law, purportedly given to Moses and Aaron in the wilderness, instructed them to slaughter an unblemished red heifer and have the old priest Eleazar sprinkle some of her blood "toward" the tent of meeting, and burn the remains to ashes. The ashes could be used to purify anyone made unclean by contact with a dead body or with a dead person's bone or a grave. The text does not say whether this procedure was to be repeated on other occasions or by later generations. ${ }^{89}$

Two other P traditions, Genesis 9:3-4 and Leviticus 17:10-14, emphatically specify that animals' blood is equivalent to their life, and therefore must not be eaten. Implicitly, their life-blood was thought to be holy, having been given them by God. What was holy could cleanse or cure persons who were ritually or otherwise unclean. Some such understanding may underlie these $P$ laws in Leviticus 14 and Numbers 19.

\section{c. Sacrifices and the Day of Atonement: Leviticus 16:1-34}

According to this PC text, a bull, a male goat, and a ram were to be sacrificed in connection with the annual day of atonement observance. Another male goat was to be "presented alive before

88. Contrast Tobit 6:4, 6-8 (fish heart, liver, and gall used for exorcism and healing).

89. Compare Deut 21:1-9, which prescribes a ceremony for "purging the guilt of innocent blood" in circumstances where someone has been killed, but the murderer undetected. Elders of the nearest city were to take a young heifer to an uncultivated valley with running water, break its neck, and then wash their hands over it. Although this ceremony is not described as a sacrifice, its stated intent was to provide forgiveness for the community that might otherwise be held accountable for "the guilt of innocent blood." (Deut 21:7-9). Nothing is said about returning its blood to the ground. Perhaps it was meant that the dead animal should either be buried or left on to decompose and thereby return to the ground. As in the case of animals sacrificed in lieu of first-born sons, the underlying sense appears to have been that the life of the animal is of the same value as the life of the human. 
YHWH" by being "sent away into the wilderness to Azazel." (16:710). ${ }^{90}$ The general idea is that these animal sacrifices would make atonement for all the sins of Israel (16:34), presumably meaning that the Israelites could thereby avoid any tangible expressions of YHWH's disfavor. This idea accords with the general priestly view that God could be influenced by sacrificial offerings. That God would accept the life of these animals instead of requiring the life of sinful Israelites, again suggests an understanding that the lives of animals and of persons were equivalent before God, the giver of all life.

\section{d. Leviticus 17:1-9: Blood Guilt for Killing Animals Other than as Gifts to YHWH}

Under terms of the Deuteronomic Reform, Israelites (or Judahites) were permitted to slaughter animals for food in their various towns, provided they did not eat the animals' blood, but instead poured it out on the ground. ${ }^{\text {.1 }}$ In contrast, the provisions of Leviticus 17:1-7 say that animals-here, specifically, oxen, lambs and goats-were not to be slaughtered unless they were then brought "to the priest at the door of the tent of meeting." $(17: 4,5) .^{92}$ The stated rationale in Leviticus 17:4 is that unless this procedure is followed, "blood guilt shall be imputed to that man; he has shed blood." The implication is that unless an animal is offered to $\mathrm{YHWH}$, its slaughter violates the animal's life or integrity as one of YHWH's creatures. Its blood is its life. (Gen 9:3-4; Lev 17:10-14). The animal's life came from YHWH; when it is killed, its life should be returned to Him. If this text is properly attributed to $P$ tradition, it may be seen as an attempt to re-sacralize the killing of animals for food, in opposition to the secularization of slaughter allowed earlier in Deuteronomy 12:15-16, 20-25. The text also could be seen as an attempt to assert the Jerusalem priesthood's claim to receive portions of animals killed for food. Choice portions of peace offerings (Lev 17:5) were said, elsewhere in $P$ tradition, to be "a perpetual due from the people of Israel" for the priests. (Exod 29:28; Lev 7:28-36). Burnt offerings referred to in Leviticus 17:8-9, however, were not eaten by

90. Whether Azazel was thought to be a place in the wilderness or a spirit of some sort is not entirely clear, though the latter meaning is commonly assumed. It is unclear whether the goat sent into the wilderness was expected to survive there.

91. Deut 12:15-16. See V.B.2.b.

92. Compare Lev 17:8-9. 
anyone, but instead offered in their entirety as "a pleasing odor to YHWH." (Lev 1:2-17.) ${ }^{93}$

\section{e. Numbers 28:1-29:40: YHWH's Food and Sabbath Burnt Offerings.}

The reference in Numbers 28:2 to burnt offerings as YHWH's "food" is unusual. Perhaps the thought was that by inhaling their "pleasing odor," God (YHWH) would, in effect, consume the burnt offerings.

Provision for sabbath day burnt offerings is found only here. (Num 28:9-10). Presumably these were to be carried out by priests at the tent of meeting, or later, in the Jerusalem temple. Otherwise, the extended list of sacrificial offerings and festivals here is typical of $P$ traditions elsewhere in Exodus, Leviticus, and Numbers. Since sabbath day burnt offerings are not mentioned elsewhere, it may be inferred that such sacrifices were either never fully implemented or discontinued.

\section{f. Leviticus 17:10-14: Animals' blood and reverence for life.}

According to $P$ tradition, God commanded Noah and his sons (meaning, presumably, all later humankind as well), not to "eat flesh with its life, that is, its blood." (Gen 9:4). The present Leviticus text provides a similar explanation: "For the life of every creature is the blood of it; therefore I have said to the people of Israel, You shall not eat the blood of any creature, for the life of every creature is its blood." (Lev 17:14).

Implicitly, the blood of animals sacrificed at YHWH's altar is thereby returned to Him. (17:11). The text suggests that the efficacy of the sacrifice is based on the value of the life contained in or constituted by the blood, thereby making "atonement." (17:11). When hunters kill a wild animal for food, they must "pour out its blood and cover it with dust" (17:13), thereby returning it to the ground..$^{95}$ Biblical tradition does not contemplate, much less, approve

93. The added rationale in Lev 17:7, "So they shall no more slay their sacrifices for satyrs," may be a later gloss. As to satyrs, see generally W. Robertson Smith, The Religion of the Semites 120-139, 441-446 (new ed. Adam \& Charles Black, 1907) (considering mainly how such beings were understood in extra biblical cultures).

94. See also Lev 1:2-17;21:6; Num 28:24.

95. See also Lev 7:26-27; compare Deut 12:15-16, 20-25. 
hunting or killing animals for "sport" or trophies." The life of animals that are killed for food must be respected, either by sacrificing them on YHWH's altar, thereby returning their life to Him, or in the case of wild animals-which were never sacrificed to YHWH - by pouring their blood out on to the ground." These laws were to be carried out both by Israelites and aliens sojourning among them (Lev 17:10,12, and 13), as, indeed, Noah and his sons had been commanded, according to $\mathrm{P}$ tradition in Genesis 9:4. A terser version of the prohibition against eating blood is repeated in Leviticus 19:26a: "You shall not eat any flesh with the blood in it." Implicitly, these provisions derive from and give expression to a sense of reverence, or at least respect or regard for the lives of animals killed for food.98

\section{g. Other PC Laws requiring animal sacrifices.}

Several additional new or special laws found only in the Priestly Code can be summarized briefly. In each case, the sacrifices were understood to please God (or YHWH) and to benefit those persons on whose behalf they were offered.

Leviticus 27:9-13, 26-27, 30-33: Votive offerings. These texts all have to do with votive offerings, that is, offerings voluntarily dedicated to YHWH, and how such offerings might be "redeemed," or spared from being sacrificed. Even unclean animals might be dedicated, but apparently such animals must be redeemed, since they could not be presented as sacrificial offerings. (27:11, 27). However, such animals could be sold by the priests, Moses' putative descendants and successors. (27:27). Leviticus 27:30-33 also add a new law: a tithe or tenth of all herds or flocks ("every tenth animal... that pass[es] under the herdsman's staff") must be given to $\mathrm{YHWH}$-or the priests.

96. Later rabbis strongly opposed wanton killing of animals and disapproved of hunting and hunters. Zvi Kaplan, Animals, Cruelty to, 3 Encyclopedia Judaica 5-6 (MacMillan, 1973).

97. Compare Gen 2:7, 19: (like the first man, in J tradition, all "beasts" and birds were made from the ground-to which, all alike would return).

98. See also Deut 15:19-23. However, killing animals by causing their blood to drain out may not be the most humane method of slaughter now available. See Rolston, Environmental Euhics at 83-84 (cited in note 10); Singer, Animal Liberation at 153-57 (cited in note 28) as to Jewish and Muslim slaughter procedures. It appears that reverence for the life of the slaughtered animals has given way to concern to avoid contamination by consuming the animals' blood, an entirely anthropocentric matter, and in the process, religiously grounded ethical care for the animals' interests have disappeared altogether. 
Numbers 6:9-20: Sacrifices by and on behalf of Nazirites. Both men and women might become "Nazirites," that is, persons who voluntarily undertook by oath to lead a "separate" and ascetic, though not necessarily celibate life. (6:1-21). ${ }^{99}$ This text provides that if a Nazirite candidate inadvertently had come close to a dead body, he was to offer two turtledoves, two pigeons, and a lamb in rites of purification. (6:9-12). ${ }^{100}$ And at the time he was "ordained," or consecrated as a Nazirite, he was to offer "at the tent of meeting" both a male and a female lamb, a ram, and various cereal and drink offerings. (6:13-20).

Numbers 7-8: The consecration of the tabernacle and Levites. Chapter seven describes various gifts and offerings presented in connection with the consecration of the tabernacle, and chapter eight includes instructions as to sacrifices that were to be offered in ceremonies when Levites were consecrated as assistants to the priests. The elaborate ceremonies described in these chapters supposedly took place while the Israelites were still in the wilderness. As the story is told, leaders from each of twelve tribes brought gold and silver vessels, oil and fine flour, and various numbers of animals for burnt, sin, and peace offerings in connection with dedication of the sanctuary's altar. ${ }^{101}$ Two bulls were to be offered as part of the ceremony consecrating the Levites, one as a sin offering, the other as a burnt offering. (Num 8:12). All these provisions were to apply on that particular occasion, but do not appear as laws intended for later times. Where all these animals would have come from during the Israelites' sojourn in the Sinai wilderness is not indicated. It is likely that these texts also represent a later, idealized picture based on Priestly conceptions of what God would have wanted.

Numbers 15:1-31: Offerings in the land of promise. These verses describe burnt, votive, peace, and sin or atonement offerings that were to be presented once the Israelites came into the land. These appear to derive from $P$ traditions, and are generally similar to $P$ laws set out in Leviticus with regard to sacrificial offerings in the wilderness period.

99. Samson, who appears to have been a Nazirite, was married and also indulged in various "affairs," including, but not limited to, the one with the famous Delilah. (Judges 13:816:31).

100. See part V.B.3.b.

101. Twelve bulls, 12 rams, and 12 male lambs were to be offered as a burnt offering; 12 male goats as a sin offering; and 24 bulls, 60 rams, 60 male goats, and 60 male lambs as a peace offering. (Num 7:87-88). 


\section{Animal Sacrifices: Concluding Observations}

One can only speculate as to the environmental impact of those animal sacrifices that actually were carried out in biblical times. Possibly the domestic animal population was thereby to some degree held in check. Generally there seem to have been adequate pasture lands to sustain a variety of domestic animals, and also enough wilderness areas for wildlife. Conceivably, sacrificing numbers of domestic animals could have functioned indirectly to control human population growth and thus limit some other environmental stresses. On the other hand, to the extent that domestic animals were raised in order to be sacrificed, crop and grazing lands used for their production necessarily would have reduced wilderness areas that otherwise could have provided wildlife habitat and other ecological benefits.

Biblical laws requiring animal sacrifices generally seem to have presupposed the value of animal life. Thus an animal might, under prescribed circumstances, be sacrificed instead of a first-born human; ${ }^{102}$ and certain animals' blood or life could purify or purge a person or community of guilt. ${ }^{103}$ Implicit in these provisions is an understanding that in some way, before God, such animals and humans were of equal worth. ${ }^{104}$ Nevertheless, a number of biblical texts suggest that God would have preferred the animals-which were his anyway-kept alive rather than sacrificed to Him. ${ }^{105}$ Other texts, particularly those attributed to the "classical prophets," explicitly opposed animal sacrifices. Generally these prophets emphasized that their fellow Israelites or Judahites could not evade YHWH's demand for justice, righteousness, love and mercy by offering sacrifices: in short, that YHWH could not be bought off with sacrificial offerings. ${ }^{106}$ Some such texts insist that $\mathrm{YHWH}$ did not

102. See V.A.2. and 4.

103. See V.B.3.b.

104. Later Christian theology moved away from biblical tradition's recognition that humans and nonhumans were not only different, but in many respects similar. See Barbour, Religion in an Age of Science, at 205 (cited in note 40). "Only in the early centuries of the Christian church were the differences accentuated and absolutized by the introduction of the Greek idea of an immortal soul. I will suggest that by drawing an absolute line between humanity and other creatures, later Christianity contributed to the attitudes that encouraged environmental destruction." Id.

105. See, for example, Psalm 50:9-15; Isaiah 66:1-4.

106. See, for example, Isaiah. 1:12-17. 
want such sacrifices at all, ${ }^{107}$ or that He never wanted them in the first place. ${ }^{108}$ The relatively small number of laws requiring animal sacrifices found in the early law codes ${ }^{109}$ suggests that most of such laws were of relatively late or recent origin, and that those prophets who urged that the Mosaic laws had not included a demand for sacrifices were largely correct.

Since the Deuteronomic reform, ${ }^{10}$ animal sacrifices could be offered only at the Jerusalem Temple. Necessarily, sacrificial offerings were suspended during the exile (ca. 586-538 B.C.E.) and the years immediately following, when the Temple remained in ruins. ${ }^{11}$ A similar suspension occurred later when the re-built Temple was desecrated in the time of Antiochus Epiphanes. ${ }^{112}$ After the Romans destroyed the Temple in 70 C.E., both Jews and Christians $^{113}$ adjusting their religious practices to its absence, discontinued animal sacrifices altogether.

\section{HUMANE LEGISLATION.}

Several laws found in one or more of the codes refer specifically to what commonly is called humane treatment of animals. ${ }^{114}$ Implicit in many of these is the understanding that animals, even those sacrificed to God and those killed for food, were to be treated with respect or consideration. Many of these laws express what could be called, again borrowing Albert Schweitzer's term, "reverence for life."115

107. See, for example, Amos 5:21-24; Hosea 6:6; Micah 6:6-8. See also Psalm 40:6-8.

108. Amos 5:25; Jer 7:21-24; but see Isaiah 43:23.

109. See V.B.

110. See V.B.2.

111. See Haggai 1:1-11. Isaiah $43: 23$ may reflect the situation during the exile: the exiles had not offered sacrifices both because they were in Babylon and because the Temple had been destroyed. See also Psalm 137:1-6.

112. See 1 Maccabees $1-4$.

113. According to Acks 2:46, some Christians previously had worshiped there as well.

114. Related, non-legal texts include, for example, Num 22:21-35; 2 Sam 12:1-6; Prov 12:10; Sirach 18:13. For a survey of contemporary issues apart from biblical perspectives, see Gary $L$. Francione, Animal Rights and Animal Welfare, 48 Rutgers L Rev. 397.469 (1996); and his book, Animals, Property, and The Law (Temple U Press, 1995).

115. Schweitzer developed what he called the "philosophy" or "ethic" of "reverence for life" in The Philosophy of Civilization (cited in note 2). See also his essay The Ethics of Reverence for Life, in Henry Clark, The Ethical Mysticism Of Albert Schweitzer: A Study of the Sources and Significance of Schweitzer's Philosophy of Civilization 180 (Beacon Press, 1962). Schweitzer's contribution to modem environmental awareness is examined by Jackson Lee Ice, Schweitzer: Prophet of Radical Theology 99-125 (Westminster Press, 1971). 


\section{A. New-Born Bull Calves, Lambs, Kids, and Their Mothers}

Laws found in both the $\mathrm{CC}$ and $\mathrm{H}$ appear to show special sensitivity to animal mothers and their offspring. Exodus 22:30 provided that a new first-born bull calf or lamb must be allowed to remain with its mother seven days before being sacrificed. ${ }^{116}$ Leviticus 22:26-27, which is part of the Holiness Code, goes beyond that provision and requires that all young bull calves, lambs and also kids remain with their mothers seven days before they may be offered to YHWH. In the Leviticus text, the offerings in question are burnt offerings (offerings "by fire") rather than offerings of the firstborn animals. ${ }^{117}$ Neither of these texts articulates a rationale. However, it may be inferred that both the $\mathrm{CC}$ and the $\mathrm{H}$ provisions accorded consideration for the special relation between new-born animals and their mothers. These provisions also may reflect concern for the health of the nursing animal mothers.

Leviticus 22:28 adds another new law that likewise seems to express concern or respect for the relationship between mother animals and their young. The mother cow, sheep or goat and her young - whatever its age ${ }^{118}$ - are not to be killed on the same day. The same sensitivity to the relationship between a young animal and its mother may also have informed the ancient prohibition against boiling a kid in its own mother's milk.

\section{B. On not Boiling a Kid in its Mother's Milk}

Laws prohibiting cooking ("boiling") a kid (or young goat) in its own mother's milk are found in the two earliest codes, RD and CC, and then again in the revised portion of $D$. In each case, the law is phrased in identical terms: "You shall not boil a kid in its mother's milk." (Exod 34:26b, 23:19b, and Deut 14:21b). None of these texts provides further explanation or rationale.

This prohibition which is the basis for the segregation of meat and milk cuisine in later traditionalist or orthodox Judaism, may have been based initially on humane sensibilities. ${ }^{119}$ It would have

116. See text accompanying notes $52-53$.

117. The Holiness Code does not include any provisions for offering first-borns, whether animal or human.

118. No age limits are indicated. Leviticus $22: 27$ says that the young animal may be offered as a burnt offering on the eighth day, but that practice was not mandated. The lambs to be presented as burnt offerings in Lev 23:12, 18-19 were to be a year old.

119. See George L. Frear, Jr., Caring for Animals: Biblical Stimulus for Ethical Reflection, 
been though too cruel to cook a little kid in its own mother's milk. Somewhat similar sensibilities may inform other provisions in biblical law. For instance, a new first-born male calf or lamb was to remain with his mother a full week before being sacrificed. (Exod 22:29b30). Other texts in the Covenant Code express explicit concern for animals' well-being: Exodus 23:4-5, 10-11, and 12. Several Deuteronomic texts also show compassion or concern for animals' well-being, ${ }^{120}$ and such concern may have prompted this law as well. The prohibition against boiling a kid in its mother's milk may also have been intended to prevent Israelites from participating in or emulating alien religious practices. ${ }^{121}$

\section{Affirmative Uuties to Care for Lost or Distressed Domestic Animals}

Both the $\mathrm{CC}$ and $\mathrm{D}$ include laws that require people to assist animals at risk in certain situations. Both express this affirmative duty by using prohibitive language: "You shall refrain from" leaving the animal without helping.

Exodus 23:4-5. This text says, in effect, that just because one person hates 'another, he should not take it out on the other's domestic animals. So, if someone comes upon an enemy's ox or ass that is lost or strayed, she should bring the animal back home. Or if an enemy's ass has fallen or foundered under its burden, he should help it get up again. Here "enemy" seems to be a personal enemy, rather than a national foe of some sort.

Deuteronomy 22:1-4. Exodus 23:4-5 had to do with obligations to return one's enemy's lost or strayed ox or ass, and to help him lift his fallen ass. Here, the law refers to a brother's animals. In this context, the term "brother" probably includes friends and neighbors, as well as relations. The lost or strayed animals named here are oxen or sheep (rather than oxen or asses), and the animals to be helped if they fell under their burdens include oxen as well as asses. These laws likewise express a sense of compassion for domestic animals. ${ }^{122}$ Taken together, Exodus 23:4-5 and Deuteronomy 22:1-4 appear to cover all such animals, whether belonging to friends or to enemies.

in Charles Pinches \& Jay B. McDaniel, eds, Good News for Animals? at 7, (cited in note 36).

120. See, for example, Deut 22:1-4, 6-7; 25:4.

121. See Gaster, Myth Legend, and Custom in the Old Testament at 205-51 (cited in note 72). Gaster also considers sources or parallels in other cultures. Id at 251-63. See von Rad, Deuteronomy: A Commentary at 102 (cited in note 70) (citing a Ugaritic milk spell).

122. See also Deut 22:6-7; $25: 4$. 


\section{Conservation: Birds and Their Young}

Deuteronomy 22:6-7 provides that when Israelites come upon a bird's nest where a mother bird is sitting upon her young, they may not take both the mother and the young. They may take the young birds, but must let the mother go. ${ }^{123}$ The text does not say whether the young are to be taken as food or as pets. Nor does it distinguish between clean and unclean birds. ${ }^{124}$ Only the former, presumably, might be eaten. Other laws already considered likewise show sensitivity for the relation between a mother animal and her young. ${ }^{125}$ Such concern may be present here. In any event, this law probably was prompted by interest in conservation, that is, recognition that to take both mothers and their young could endanger the survival of the species. The mother bird, it could be assumed, would live to hatch and raise many more broods of young. ${ }^{126}$ Noah's ark project, of course, was the classic biblical instance of human engagement in wildlife conservation. ${ }^{127}$

\section{E. On Not Muzzling Oxen Treading Grain: Deuteronomy 25:4}

According to this law, an ox that has been harnessed to thresh or "tread out" grain is not to be muzzled. Instead, he is to be free to eat some of the grain as he works. The underlying idea seems to be that it would be cruel to deny the ox food when he has it all around him. ${ }^{128}$ Numerous other biblical texts show consideration for oxen, as well as for cattle generally. ${ }^{129}$ Possibly Deuteronomy 22:10 also reflects concern for the humane treatment of domestic animals: "You shall not plow with an ox and an ass together." Pairing animals of such

123. The text also refers to eggs, but does not say whether they may be taken. Perhaps it was assumed that they might be.

124. Compare Deut 14:11-20.

125. See part VII. A.\& B. See von Rad, Deuteronomy: A Commentary at 141 (cited in note 70): "[T] he ordinance ... can probably be attributed only to humane motives and hardly to considerations of utility."

126. See Berry, The Gift of the Good Land at 273 (cited in note 3). "This, obviously, is a perfect paradigm of ecological and agricultural discipline.... The inflexible rule is that the source must be preserved. You may take the young, but you must save the breeding stock." Id. See also von Rad, Deuteronomy: $A$ Commentary at 141 (cited in note 70).

127. See notes 26-29 and accompanying text.

128. Compare Paul, in 1 Cor 9:8-11, who interprets the text allegorically to mean that a human missionary is worthy of the benefits of his office.

129. See Gen 8:1; Exod 22:30; 23:4; Lev 22:26-28; Deut 22:1-4; Psalm 50:10; Isaiah 66:3; Jonah 4:11. 
different sizes could be harmful to one or both..$^{130}$

\section{F. Sabbath Days and Years of Rest for the Benefit of Cattle and Wildlife}

That the Sabbath was a day of rest for domestic animals as well as for Israelites is stipulated in the Ten Commandments as found in both the CC and D. A separate law to the same effect also appears in the $\mathrm{CC}$. The $\mathrm{CC}$ and $\mathrm{H}$ additionally provide for animal welfare in laws concerning the seventh or sabbatical year of rest.

\section{The Sabbath Day of Rest}

Exodus 20:10. The Sabbath law is part of the decalogue or "ten commandments."131 Neither humans ("you, or your son, or your daughter, your manservant, or your maidservant... or the sojourner") nor cattle are to do any work on the Sabbath. Here, as elsewhere in biblical discourse, "cattle" probably includes all kinds of domestic animals. Sabbath observance honors not only YHWH, who made all creation in six days and then rested on the Sabbath or seventh day (20:11); it also is a day of rest, for the well-being of both man and beast.

Exodus 23:12. This law, likewise found in the CC, so states in explicit terms: "Six days you shall do your work, but on the seventh day you shall rest; that your ox and your ass may have rest, and the son of your bondmaid, and the alien, may be refreshed." The Sabbath was to be a day of rest for humans and animals alike.

130. Thus Schorsch, Learning to Live with Less in Rockefeller \& Elder, eds, Spirit and Nature at 31 (cited in note 10). Such Biblical laws have had some influence on American Jurisprudence. See Stephens v State, 3 So. 458, 458-59 (Miss. 1888), quoted in Steven M. Wise, The Legal Thinghood of Nonhuman Animals, 23 BCEnv Affairs L Rev 471, 542 (1996).

The common law recognized no rights in ... animals, and punished no cruelty to them, except in so far as it affected the rights of individuals to such property. Such statutes [as that in question] remedy this defect, and exhibit the spirit of that divine law which is so mindful of dumb brutes as to teach and command, not to muzzle the ox when he treadeth out the corn; not to plow with an ox and an ass together; not to take the bird that sitteth on its young or its eggs; and not to seethe a kid in its mother's milk. To disregard the rights and willfully or wantonly injure or oppress the weak and helpless, is mean and cowardly. Human beings have at least some means of protecting themselves against the inhumanity of man ... but dumb brutes have none. Animals whose lives are devoted to our use and pleasure, and which are capable, perhaps, of feeling as great physical pain or pleasure as ourselves, deserve, for these considerations alone, kindly treatment.

131. Slightly different versions of the "ten commandments" appear in Exodus 20:1-17 and Deut 5:6-21. 
Presumably this law applied only to "work" animals, such oxen, and asses, which are here named in particular. ${ }^{132}$ Others, such as sheep and goats, we may assume, were free to go about their browsing and other customary activities on the Sabbath as on other days.

Deuteronomy 5:12-15. This version of the sabbath law is much like that in Exodus 20:8-11, but with a slight difference. Here, the day specifically is set apart for the people of Israel (and also sojourners) to "rest." The Exodus version says that the Israelites' cattle are to do no work this day. The D version states that no work is to be done by oxen, asses, "or any of your cattle." (Deut 5:14). Exodus 23:12 specified that YHWH's people were to rest on the seventh day so that their oxen and asses might have rest. The Deuteronomic version, however, could be read to mean that the cattle were to rest so that the Israelites' manservants and maidservants may also rest, that is, be relieved of working with or otherwise tending the cattle. If so, we see a slight shift from theocentric to a more anthropocentric rationale. ${ }^{133}$ Such a shift may also be seen in another difference between the two versions of the sabbath law. In Exodus 20:11, the sabbath is to be observed because YHWH rested on and blessed the seventh day; in Deuteronomy 5:15, reference instead is to the experience of Israelites as servants in Egypt. Here the rationale seems to be that because the Israelites should remember what it was like to be servants (or slaves) in Egypt, they ought to show kindness to their own servants by allowing them to rest on the sabbath day. This rationale, unlike that articulated in Exodus 23:12, does not specifically indicate concern for the wellbeing of the work animals.

\section{The Sabbath Year of Rest}

Exodus 23:10-11. This law, part of the CC, requires that after six years of sowing and harvesting, the land shall be allowed to rest and lie fallow. ${ }^{134}$ The stated rationale is to provide for the needs of

132. Compare Deut 5:14, which also refers specifically to oxen and asses.

133. On the signficant difference between theocentric and anthropocentric ethics, see generally James M. Gustafson, A Sense of the Divine: The Natural Environment from a Theocentric Perspective (Pilgrim Press, 1994). Compare Thomas S. Derr, Environmental Ethics and Christian Humanism (Abingdon Press, 1996) (undertaking to make a strong case for anthropocentric environmental ethics); and see James A. Nash's critique of Derr's position. Id at 105-124.

134. See VII.B. 
the poor who, under terms of the law, were entitled to harvest whatever grew during the seventh year. ${ }^{135}$ In addition, this law was intended to provide forage for wildlife: what the poor left, the "wild beasts" could eat. Similar provisions appear in Leviticus 25:2-7.

Leviticus 25:2-7. As just noted, the Covenant Code provided that the seventh year should be a year of rest for the land, and that the poor and wild beasts might freely eat of its produce that year. (Exod 23:10-11). Similarly, according to this $\mathrm{H}$ text, the land should not be worked during the seventh year, but should be allowed to "rest." Landowners, and presumably their families and other workers, servants or slaves, were to rest, too. Fields were not to be sown, nor vineyards trimmed; what grew was not to be reaped, nor grapes gathered. (Lev 25:4-5). How the land was to provide food for people $(25: 6)$ if they were not to reap or gather is not clear here. This question is addressed later in Leviticus 25:20-23, and answered with the assurance that the sixth year, the crop would be bountiful enough to provide for the next two years besides. ${ }^{136}$ What grew the seventh year would provide food not only for people, but also for "cattle" (domestic animals) and "beasts" (wildlife) alike. (25:7). ${ }^{137}$ As in the case of YHWH's telling Noah to provide food for the animals on the ark, ${ }^{138}$ YHWH instructs Israel (through Moses) to make provisions for cattle and wildlife-by allowing them to graze freely throughout the seventh year on what otherwise would have been cultivated fields, vineyards and orchards. According to Leviticus $25: 8-12$, the $50^{\text {th }}$ year-the year of Jubilee-would also be a time of rest for the land. There would be no sowing, reaping, or gathering. Perhaps this, too, would be a time when, as in the sabbatical year, "cattle" and "beasts" were to enjoy the yield of fields, vineyards and orchards. (25:6-7).

\section{OTHER LAWS AFFECTING ANIMALS}

In addition to laws that specifically aim at humane treatment of animals or preservation of species, several other laws governing treatment of animals had definite implications for their well-being.

135. Compare 2 Kings 19:29-31, which refers to a two-year period when, after the Assyrians withdrew from Jerusalem, the people of Judah would "eat what grows of itself."

136. Compare Exod 16:22-30.

137. As to YHWH's providing food for wildlife, see also Job 38:39-41; 39:5-8; Psalms 104:26-28; $145: 15-16$.

138. Gen 6:21-22. 
Laws that value animals primarily as property are not considered here. ${ }^{139}$

\section{A. The Anti-Buggery Statutes}

Both the $\mathrm{CC}$ and $\mathrm{H}$ include laws prohibiting sexual intercourse with animals. In old British and American law, the offense is labeled "buggery." Two versions of such a law are found in $\mathrm{H}$.

Exodus 22:19 makes "buggery," that is, a human's sexual intercourse with an animal, a capital offense. The human was to be put to death, but not the animal. No rationale is given for the prohibition or the seriousness of the penalty. Perhaps it was meant to protect the animals from abuse or the species from genetic contamination. $^{140}$ Or possibly the prohibition stemmed from an intuited concern lest animal diseases be transmitted to humans. Or it may be that such intercourse was banned because it was associated with the worship of other gods. ${ }^{141}$

Leviticus 18:23 provides another rationale for the prohibition: a man is not to have sexual intercourse with any beast lest he thereby defile himself. Nor should a woman do so, for "it is a perversion." In contrast to Exodus 22:19 and the version in Leviticus 20:15-16, this text does not state that the person who commits such an act must be put to death.

Leviticus 20:15-16. Exodus 22:19 provided that whoever lay with a beast was to be put to death. Here, as in Leviticus 18:23, the text specifies that the law applies to both men and women. As in Exodus 22:19, the offense is capital, in contrast to Leviticus 18:23 where no punishment is mentioned. Unlike both earlier versions, this law provides that the beast was also to be put to death. Perhaps the theory was that the beast had been contaminated and thus would be ritually, genetically, or otherwise "unclean" and unfit either as a

139. See, for example, Exod 21:35-36 (when one person's ox causes the death of another's); Exod 21:33-22:1, 4-6, 9-15; Lev 24:17-18, 21 (laws providing for restitution). See also Exod 21:28-32 (when an ox kills a person). Steven $M$. Wise examines biblical laws concerning goring oxen as a measure of biblical attitudes toward animals. Wise, 23 BC Env Affairs L Rev at 476. 88 (cited in note 130). He concludes that the Covenant Code's insistence upon "capital punishment" for oxen who have killed humans reflects an anthropocentric and hierarcnical cosmology, and contributed to modern legal treatment of animals as mere things. Id at 488 . Arguably, these provisions could be said instead to indicate that such oxen were regarded as accountable beings, like humans who killed other humans, rather than merely as things.

140. Compare Lev 19:19.

141. The verses immediately preceding and following, Exod 22:18, 20, prohibit certain alien religious practices. 
sacrificial offering or for food. Biblical tradition does not generally include "case reports" or decisions; but it may be noted that none of the biblical narratives reports instances in which "buggery" actually occurred or where humans or animals were executed for committing that offense.

B. Flesh torn by beasts: for the dogs. Exodus 22:31.

Israelites were not to eat the flesh of animals injured or killed by wild beasts or predators. This law may reflect the understanding that an animal killed for food should first be sacrificed to God. The Covenant Code does not prohibit consumption of blood or require that an animal's blood be poured out on the ground. Those requirements first appear in $\mathrm{H}$ and $\mathrm{P}$ laws. But they may also underlie this provision. Or it may be that Exodus 22:31 reflects some sense that such flesh might be contaminated and unsafe to eat. In any event, it was not to be wasted by being buried or left to rot. Instead, it was to be "cast to the dogs." This is the first biblical mention of dogs, domesticated or otherwise. Though the text does not expressly mention concern on their behalf, it provides that dogs were to have the benefit of such food. ${ }^{142}$

\section{Clean and Unclean Animals}

Some hundred and twenty different kinds of animals are named in the Bible, including 37 kinds of mammals, 38 kinds of birds, and 12 types of reptiles. ${ }^{143}$ The laws provided that Israelites or Jews might eat some, but not most of these. The more extended $P$ version is considered first.

Leviticus 11:1-47: The longer list. The distinction between "clean" and "unclean" animals appears as early as Genesis 7:2-9, in J tradition specifying the numbers of pairs of animals that were to be taken onto the ark. From the standpoint of $P$ tradition, however, such distinction was first made-so far as Israelite or Jewish dietary practices are concerned-in the law YHWH gave Moses at Mt. Sinai. That law is now set out in this text.

142. Somewhat more positive references to dogs' relations to humans are found in Tobit 5:16; 11:4; Matt 15:21-28; Mark 7:24-36; Luke 16:20-21.

143. See the detailed description by Juhuda Feliks, Animals in the Bible and Talmud, 3 Encyclopedia Judaica 7-19 (1972). See also Roger Caras, The Promised Land, Israel, for Biblical Beasts, 3 Wildlife 3, 4-13 (1973) (biblical wildlife preserves in modern Israel). 
Animals that Jews might eat included the following: all "beasts" with parted hooves (or "cloven" feet) that chew their cud; "everything in the waters" with fins and scales; implicitly all birds except several enumerated species; ${ }^{14}$ and "winged insects that go on all fours," provided they "have legs above their feet with which to leap," namely, locusts, ${ }^{145}$ crickets, and grasshoppers. Living creatures not to be eaten included, among four-footed animals, whichever did not both have cloven hooves and chew their cud, notably camels, badgers, hares, and swine, ${ }^{146}$ whatever is in the water, but does not have both fins and scales; and certain birds (especially raptors), namely eagles, ospreys, kites, falcons, ravens, ostriches, night-hawks and other hawks, sea gulls, cormorants, ibises, "water hens," pelicans, vultures, storks, herons, "hoopoes," and (misclassified here as birds) bats. All other insects "that go upon all fours" were considered "unclean." Likewise, all kinds of "swarming things," including weasels, mice, lizards, geckos, crocodiles, chameleons, "whatever goes on its belly," and "whatever has many feet" were not to be eaten. (Lev 11:29-30, 41-42).

Some of these restrictions may derive from health or sanitary considerations as well as from more ancient dietary customs or prejudices. Moreover, since the Israelites were to be a holy ("clean" or "separate") people, it was fitting for them to eat only what YHWH declared to be "clean."147 Unclean animals were not, however, expendable. They were not to be destroyed or exterminated just because they could not be eaten or otherwise used by humans. As was explictly the case in the P flood story where all kinds of land and air creatures were preserved, so here, implicitly, the innumerable species of unclean animals were seen as valued by God and worthy of existence, even though inedible. ${ }^{148}$

Deuteronomy 14:3-20: The shorter list. This Deuteronomic list is briefer, less detailed, and may be earlier than the PC version found in

144. Compare Lev 11:46-47. Curiously, the text does not say explicitly that other birds might be eaten. Compare Deut 14:11, 20.

145. Compare the diet of John the Baptizer, according to Matt 3:4.

146. Included under these criteria, but also specified, are all animals "that go on their paws... on all fours" (Lev 11:27). This category would include bears, wolves, many other woods creatures, dogs, and all kinds of feline animals. Horses and asses (or donkeys), though not specifically mentioned, also would be excluded because they do not chew their cud.

147. See, for example, Lev 11:44-47.

148. Contrary to the views expressed in 2 Esdras 6:55 \& 7:11, biblical tradition does not hold that the world was created for the sake of Israel, or even of all humankind. 
Leviticus 11:1-47. ${ }^{149}$ The lists are so similar as to prompt the conclusion that either one derived from the other, or that both drew upon a common source. Nevertheless, even though the general principles are the same as to land animals (clean animals have cloven hooves and chew their cud), there are some differences. Deuteronomy 14 names several animals that may be eaten that are not listed specifically in Leviticus 11: oxen, sheep, goats, harts, gazelles, roebucks, wild goats, ibexes, antelopes and mountain sheep. Among birds that may not be eaten, the Deuteronomic list includes buzzards and identifies both the "the little and the great owl"; while Leviticus 11 includes two missing in the Deuteronomic list: the falcon and the ibis. The Deuteronomic list also lacks any mention of fourfooted animals that go on their paws (Lev 11:27) and "swarming things" named in Leviticus 11:29-30, namely, weasels, mice, lizards, geckos, crocodiles and chameleons. The Deuteronomic law bars entirely "all winged insects" (Deut 14:19), while Leviticus 11 allows some to be eaten. (11:20-23). As with Leviticus 11, so here also, unclean animals were not said to be worthless, nor were they to be destroyed. They just were not to be eaten. An important, if perhaps unintentional consequence of the clean/unclean distinction, was that the numerous categories of "unclean" animals were spared the prospect of becoming food for Israelites and Jews. These restrictions contrast with Genesis 9:1-3, which says that God gave Noah and his sons all kinds of living creatures for food.

\section{Applied Genetics: Leviticus 19:19}

The root meaning of Holy (qadosh) in Hebrew is "separate" or "distinct," as well as "clean" or "pure." Israel was to be "separate" or different from other nations and was to distinguish carefully between what is clean and unclean. (Lev 22:22-26). This verse's emphasis on keeping things distinct is characteristic of $\mathrm{H}^{150}$ This provision bars cross-breeding different kinds of cattle. Schorsch suggests that it expresses "respect for the divine ordering of animate things." Hist Human involvement in protecting, if not promoting different genetic strains is here viewed positively. Maintaining

149. It is possible, of course, that later $P$ editors could have inserted this abbreviated list into the book of Deuteronomy.

150. See also Deut 22:9-11.

151. Schorsch, Learning to Live with Less in Rockefeller \& Elder, eds, Spirit and Nature at 32 (cited in note 10). 
diverse kinds of cattle requires human attention and care. As the biblical story is told, Noah, the forefather of all subsequent humankind, was famous above all for undertaking to preserve genetic diversity. ${ }^{152}$

\section{E. The Herem}

Herem is a Hebrew term referring to destruction of persons (and also animals and property) associated with the worship of other gods. It is described in several narrative texts, particularly in Deuteronomy and Joshua, some of which say that the Israelites' enemies and also their cattle were to be devoted or destroyed. Certain laws found only in D so provided. It is not clear to what extent the herem actually was practiced by ancient Israelites.

Deuteronomy 13:12-18: Apostate and idolatrous Israelite cities, their people, and cattle. Deuteronomic tradition persistently, and here fiercely, insists that Israelites worship only YHWH. If the inhabitants of an Israelite city have been induced to worship other gods, they were all to be destroyed, and their cattle with them. (Deut 13:12-15). Possibly it was believed that in such instances the cattle would have been consecrated to other gods, in which case, any Israelite who later ate their meat would commit a kind of technical idolatry. A somewhat related problem troubled one of the early Christian communities where meat sold for food sometimes came from animals that had been sacrificed to pagan deities. ${ }^{13}$ The Bible does not report that any Israelite cities, or their people or cattle actually were destroyed pursuant to this law.

Deuteronomy 20:10-18: Laws of conquest. If the Israelites had occasion, as they advanced toward the promised land, to fight against a city along the way, and that city refused to surrender, the Israelites were to kill all its men, but take its women, children and cattle as

152. See Rolston, Environmental Ethics at 23 (cited in note 10).

A thoroughgoing humanist may say that only personal life has value, making every other life form tributary to human interests, but a sensitive naturalist will suspect that this is a callous rationalization, anthropocentric selfishness calling itself hard science. The first lesson learned in evolution was perhaps one of conflict, but a subsequent one is of kinship, for the life we value in persons is advanced from, but allied with, the life in monkeys, perch, and louseworts. Mixed with other values, this Noah principle of preserving breeding population is powerfully present in the Endangered Species Act.

See also text accompanying notes 26-29.

153. 1 Cor $8: 1-13 ; 10: 18-32$. 
spoils of war or booty. (Deut 20:12-15). ${ }^{134}$ But in the case of cities within the land of promise, the Israelites were to "save alive nothing that breathes." (20:16). The given rationale was that any human survivors might corrupt the Israelites by teaching them "to do according to all their abominable practices which they have done in the service of their gods," and thereby "sin against YHWH." (20:18).

\section{THE LAND}

Whatever else may have been meant by the $\mathbf{P}$ tradition authorizing antediluvian humans to "subdue the earth" (Gen 1:28), ${ }^{135}$ that text did not license exhaustion of the earth's resources or its degradation. ${ }^{156}$ On the contrary, a land ethic is implicit (and sometimes explicit) in much of biblical law. Ultimately, the land belongs to YHWH or God, not to Israel or even to all humankind. And YHWH cares for the earth, including, and in special ways, the land of Israel. ${ }^{157}$ A number of laws require explicitly that the land must be allowed to rest periodically. Others provide ways to prevent pollution of the land. And several underscore the conditional and impermanent character of Israel's tenancy on the land.

\section{A. The Land is YHWH's, not Israel's}

Both creation stories (Gen 1:1-2:4a and 2:4b-24) could be read to mean that the earth and everything in it, being made by God (or YHWH), belong to Him. That the earth belongs to YHWH is said explicitly in Exodus 19:5: "All the earth is mine." Several other biblical texts affirm the same thing. ${ }^{1.5}$ This theme appears in a

154. Compare Deut 2:26-3:7, where the narrative states that the Israelites destroyed "every city, men, women, and children," but saved the cattle and other spoil as booty.

155. See text accompanying notes 5-13.

156. See Steck, World and Environment at 107 (cited in note 3).

The limitations laid down in Genesis 1 show that for $P$ the possibility of an exploitation of the earth to the point of the exhaustion of its resources, or the contingency that autocratic man might poison and destroy living space on earth, is not remotely considered in this authorization. The subjection of the earth is only so that man may be supplied with useful plants—and, in addition the passage presupposes a permanent and completely sufficient supply of wild vegetation for the nourishment of wild animals, birds, and creeping things. Gen 1:30.

157. See, for example, Deut 11:11-12; Job 38:25-27. See generally Wendell Berry, The Gift of Good Land: A Biblical Argument for Ecological Responsibility, 64 Sierra 20-26 (Nov/Dec 1979).

158. See, for example, Exod 9:29b; Deut 10:14; Psalms 24:1-2; 50:10-12. See generally Anderson, From Creation to New Creation at 1-18 (cited in note 2); Santmire, The Travail of Nature at 190-92 (cited in note 2). 
number of biblical laws and related texts. For his own purposes, YHWH has given his people, Israel, a kind of tenancy on the land. Such tenancy, however, is to be distinguished from the kind of possession known in law as "in fee simple absolute."

Exodus 19:4-6 clearly implies that YHWH will give the people of Israel a particular space and place on earth-provided they remain faithful to his commands and covenant. Other texts likewise express the contingent nature of Israel's occupancy of the promised land once settled there. ${ }^{159}$

Deuteronomy 10:14. This text states the matter in explicit terms: to YHWH belong "heaven and the heaven of heavens, the earth with all that is in it." In effect, the whole creation is YHWH's. Similar affirmations appear in some of the psalms, such as Psalms 24:1-2, 50:12, and 89:11. The implicit corollary is that the world does not belong to humans to do with as they please.

Leviticus 25:23. This text clearly means that the land ultimately belongs to YHWH. The land in question here probably is the land of promise or Canaan. The sense of YHWH's ownership of land is not necessarily limited to that land, however. Other texts indicate what is already implicit in the creation narratives, that all that is belongs to YHWH, including the land. ${ }^{160}$ Land therefore may not be sold "in perpetuity," i.e., so as to become anyone's permanent possession. The people of Israel are "strangers and guests" there. ${ }^{161}$ People may buy and sell land-subject to laws or rights of inheritance and redemption, ${ }^{162}$ but in the end, it is YHWH's to dispose of as $\mathrm{He}$ chooses. This text could be read to suggest a "land ethic," that is, that the land is to be seen always as God's gift, not something to be exploited and degraded for human gain. ${ }^{163}$ As generally is the case with a theocentric, in contrast to anthropocentric ethics, this biblical text could also imply that the land is for the benefit of other beings

159. See, for example, Hosea 4:1-11:7; Amos 3:1-9:8a; part VIII.D. See generally Geoffrey R. Lilburne, A Sense Of Place: A Christian Theology of the Land 45-54 (Abingdon Press, 1989).

160. See, for example, Deut 10:14 ("Behold, to YHWH your God belong heaven and ... the earth with all that is in it"); Psalm 24:1 ("The earth is YHWH's ...").

161. See John Hart, The Spirit of the Earth: A Theology of the Land 51-55, 119-23 (Paulist Press, 1984).

162. Leviticus 25 and 27; see Raymond Westbrook, Property and the Family in Biblical Law 2435, 53, 58-68 (JSOT Press, 1991); Richard H. Hiers, Transfer of Property by Inheritance and Bequest in Biblical Law and Tradition 10 J Law \& Relig 121 (1993-94).

163. See Berry, The Gift of the Good Land at 269-81 (cited in note 3). 
besides humans. $^{164}$

\section{B. Sabbath Rest for the Land}

Several biblical laws provide that the land itself was to be allowed to "rest" periodically. None of the sabbath day commandments ${ }^{165}$ mentions the land's resting, but implicitly the land, itself, would rest on sabbath days, for no one would work upon it. ${ }^{166}$

Exodus 23:10-11 provides that after six years of sowing land and gathering its yield, Israelite farmers were to let the land "rest and lie fallow" on the seventh or Sabbatical year. Israelite farmers probably did not practice crop rotation or other modern soil conservation strategies. The sense of this law is that the land itself desired or needed a rest after producing crops for six consecutive years. Likewise, vineyards and olive orchards were to be allowed to rest. (Exod 23:11). ${ }^{16}$ The Jubilee Year provisions in Leviticus 25 likewise provided for the land to rest during the sabbatical year. ${ }^{168}$

Leviticus 26:34-35, 43: The exile-an extended sabbath for the land. Chapter 26 probably concludes the Holiness Code. YHWH is still speaking, presumably through Moses. ${ }^{169}$ Leviticus 26:3-13 describes how the Israelites will prosper if they observe YHWH's statutes and commandments. But the writer seems to have known (if not foretold) that the people of Israel would miserably fail to do so. Verses $14-45$ appear cognizant of the sixth century B.C. Babylonian conquest of Judah and the subsequent exile. What would become of the land of Judah when its people were deported into exile? The land itself would enjoy a long "sabbath rest"-in compensation for the Israelites'/Judahites' failure to observe the old requirements providing that the land itself should rest every seventh and $49^{\text {th }}$ or $50^{\text {th }}$ year. ${ }^{170}$ Here, as in those texts, we see that the land itself was to be respected and protected against over-use.

164. Compare Exod 23:10-11; Lev 25:2-7.

165. Exod 20:8-11; 23:12; Deut 5:12-15.

166. See part VI.F.1.

167. See also Lev 25:2-7, 8-12, considered in part VIF2. See Westbrook, Property and the Family in Biblical Law at 37 (cited in note 162). "There is no mention of the poor [in Lev 25]; however, the reason assigned is that the land, being God's land, must keep the Sabbath, that is, the Sabbath principle is extended to cover nature as well as man." Id.

168. See part VI.F.2. of this article.

169. Compare Lev 25:1.

170. Exod 23:10-11; Lev 25:1-12. 


\section{Against Pollution of the Land}

In biblical times, modern toxic chemical and biological pollutants, of course, were unknown. But biblical law did express concerns about other ways by which human actions could pollute the land. Failure-by Israel, Judah, or even all humankind-to adhere to YHWH's "everlasting covenant" by violating his commandments and statutes pollutes the earth, wrote a late Isaianic prophet. (Isaiah 24:5). The "everlasting covenant" referred to here probably was the covenant "between God and every living creature of all flesh" characterized in Genesis 9:16 as "the everlasting covenant." Biblical laws identify other related types of pollution.

Deuteronomy 21:22-23: Keeping the land undefiled. A criminal executed for committing a capital offense might afterwards be hung or impaled on a tree. Perhaps this form of punishment was intended to deter others from committing such heinous offenses. ${ }^{172}$ This law provides that the executed offender's body must be taken down and buried the same day, lest the land be defiled. As in Numbers 19:1-22, the theory may have been that contact with or even proximity to a dead body causes a person to be ritually unclean, and that others who had contact with a person so contaminated would spread further defilement. This law may also reflect public health concerns based on experience.

Deuteronomy 23:12-14: Sanitary arrangements. This law prohibits the people of Israel from polluting their "camp" with their excrement. When need to defecate arises, they are to go outside the camp to a designated area, taking along a digging stick; there, they are to make a hole, use it, and cover it up with earth afterwards. This law was to apply during the Israelites' sojourn in the wilderness, and also, perhaps, after they had entered the land of promise. Thus they were to keep their land both ritually clean or "holy" and sanitary. Urban sanitary arrangements are nowhere mentioned.

Numbers 35:30-35: Cleansing the land of bloodshed. Numbers 35 makes a distinction between manslaughter and murder. The present verses insist that a murderer be put to death, but only if more than one witness testifies as to the accused's guilt, presumably at a

171. See part III of this article.

172. Compare Deut 19:19 which articulates deterrence theory in connection with the punishment of malicious witnesses and applies the lex talionis in that context. (Deut 19:16-21).

173. Biblical tradition contains few other references to defecation: 1 Sam 24:3; 1 Kings 18:27. 
trial of some sort. ${ }^{174}$ Numbers 35:33-34 seems to say that human blood shed by a murderer pollutes or defiles the land, and that the only way this pollution can be removed or expiated is "by the blood of him who shed it."175 The purpose of this law was neither retribution nor deterrence, but rather to cleanse the land.

\section{Israel's Contingent Possession of the Good Land}

Several texts associated with biblical law underscore the tenuous nature of Israel's occupation of the land promised to them and their forebears in the covenants of old. These texts may derive from sermons or exhortation at ancient tribal gatherings when the law was read and the covenant renewed. In any case, they called on Israelites to adhere to YHWH's law. YHWH had made good on his promise to bring his people into this land. Now it was up to them to remain faithful to YHWH and his commandments, ordinances, and statutes.

Deuteronomy 6:3, 10-19: The peril of apostasy. Again "Moses" (or YHWH) characterizes the land of Canaan as "a land flowing with milk and honey." (Deut 6:3). Moreover, it is a place of "great and goodly cities," houses, cisterns, vineyards, and olive trees. (6:10-11). But YHWH will destroy his people "from off the face of the earth" if they forget Him and worship other gods instead. ${ }^{176}$ The land is characterized explicitly as "the good land" which YHWH had promised to give their fathers. (6:18).

Deuteronomy 8:7-20: The peril of autonomous individualism. In this exhortation, Moses (or some later spokesperson for YHWH) draws attention to the rich resources with which the promised land is blessed: brooks of water, fountains and springs, wheat, barley, vines, fig trees, pomegranates, olive trees and honey, iron and copper, a land in which they "will lack nothing." (Deut 8:7-9). The peril is that the Israelites might forget YHWH and his commandments, and, when they became prosperous, come under the illusion that their own power and might had gotten them this wealth. (8:17). Those who presume to be masters of the earth, are likely to lose their respect for it, along with their reverence for the God who-for a

174. Compare the trial scene in Susanna vv $28-60$.

175. Compare the procedure prescribed in Deut 12:1-9, where the murderer had not been found. See part V.B.3.b. See generally Gaster, Myth Legend and Custom in the Old Testament at 69-72 (cited in note 72).

176. See also Deut 7:1-11. 
while-entrusted it to them. ${ }^{17}$

This is the first and only text in the Bible regarding mineral removal or extraction: "a land whose stones are iron, and out of whose hills you can dig copper." (Deut 8:9). The Israelites were free to use these resources, but there was no permission, much less, any injunction or commandment to use them up or degrade the environment in the process. ${ }^{178}$

Deuteronomy 9:4-24: The peril of moral complacency. Deuteronomy 9:4-6 cautions Israelites against believing that YHWH has favored them in the past and will maintain them forever in the promised land because they have been a righteous people. They have not been righteous, but rather "are a stubborn people," with a history of acting corruptly and rebelling against YHWH. (9:6-8, 12$16,22-24$, and 27). The central theme in the Book of Deuteronomy is that the Israelites' conduct must change radically for the better-or else they would lose it all.

Both in Israelite tradition, and in the early Christian community represented in the New Testament, it was understood that only those who remained faithful to God, who had regard for his commands and purposes, would retain or inherit the blessings of life in the promised land of Canaan, or in the messianic age to come. ${ }^{179}$

\section{TREes AND Plants}

Biblical tradition consistently attributes the creation of the earth and all that grows and lives upon it to God or YHWH. Biblical laws focus sometimes on the earth or land itself, and sometimes on trees and other vegetation. Texts relating to trees will be considered first.

177. Compare Lev 25:23: "[T]he land is mine; ... you are strangers and guests with me." Translation by Hart, The Spirit of the Earth (cited in note 161).

178. Compare former Interior Secretary James Watt's explanation for his decision to open 800 million acres of federal land for corporate exploitation: "My responsibility is to follow the Scriptures which call upon us to occupy the land until Jesus returns." (Maclean 94 (June 15, 1981) 41). There is, of course, no such biblical text or requirement. Robert Lekachman's Greed is Not Enough Reaganomics 51 (Pantheon Books, 1982): "At his confirmation hearing, Mr. Watt casually confided to the senators in attendance that 'I do not know how many future generations we can count on before the Lord returns.'... [T] his uncertainty appeared, mysteriously to justify opening of public lands to coal miners, oil explorers, lumbermen, resort developers, stock grazers, and other predators. Scripture, asserted Mr. Watt, endorsed his plan." As to Protestant fundamentalist pre-occupations vis-à-vis environmental concerns, see Fowler, The Greening of Protestant Thought at 45-57 (cited in note 3).

179. On New Testament expectations, see summary of recent scholarship by McAfee, Ecology and Biblical Studies at 38-41 (cited in note 2). 


\section{A. Trees}

According to the $P$ narrator, trees were among the good things God had created at the beginning (Gen 1:11-12); and in the J creation story, YHWH himself planted the Garden of Eden and made to grow there not only the two special trees of life and of knowing good and evil, but also "every tree that is pleasant to the sight and good for food." (2:9). Other texts indicate that fig trees were especially appreciated. ${ }^{180}$ Several texts affirm that trees were valued and cared for by YHWH and recognize their importance as wildlife habitat. ${ }^{181}$ Not only animate beings, but trees, too, are among YHWH's creations called upon to praise Him. ${ }^{182}$

\section{New Orchards}

Leviticus 19:23-25 suggests that when the Israelites came into their eventual homeland, they were required to plant fruit, nut, and olive trees ("all kinds of trees for food"). The law specifies that fruit from these newly-planted trees should not be eaten during the trees' first three years. Perhaps it was believed that such young trees needed all their energy to grow. ${ }^{183}$ Though not expressly mentioned, it might be expected that fruit that was left on the trees or dropped off would provide food for wildlife. The fourth year, the trees' fruit was to be "holy," an "offering of praise" to YHWH. How it was to be offered is not clear: perhaps it would be taken to a local sanctuary and either placed on an altar or, as with certain other offerings, distributed to the poor and needy. ${ }^{184}$ In any event, the fourth year provision expresses thanks or praise to $\mathrm{YHWH}$ for providing the trees' fertility and fruition.

\section{2. $\quad$ Of Trees and War}

According to Deuteronomy 20:19-20, when the Israelites besieged a city for a long time, they were not to "destroy its trees by

180. See, for example, Prov 27:18; Zech 3:10; Micah 4:4; compare Luke 13:6-9.

181. See Job 40:21-22; Psalm 104:16-17; Ezek 17:22-24; but see Matt 13:31-32; Luke 13:1819.

182. See, for example, Psalm 148:9 ("fruit trees and all cedars"); see also Song of the Three v 54 ("all things that grow on the earth").

183. This is the second instance of "forbidden fruit" in biblical tradition. The first, of course, was the "tree of knowing good and evil." (Gen 2:16-17).

184. See part IX.B.4.b. 
wielding an axe against them." The first stated rationale is that the trees might later provide them food. But then YHWH (or Moses) asks, rhetorically: "Are the trees in the field men that they should be besieged by you?" Only trees known not to be "trees for food" could be cut down. Others were not to be destroyed wantonly, but only for the purpose of building siege works. This law was understood to apply in warfare against cities, whether within the promised land or en route to it. Deuteronomy 20:19-20 suggests that all trees were understood to be part of God's good creation and should ordinarily be left alone to live and grow. ${ }^{125}$

\section{Trees and the Destruction of Asherim}

The Deuteronomic reform program called for destruction of the shrines where Canaanites and other nations had worshiped their gods "upon the high mountains and upon the hills and under every green tree." (Deut 12:1-2). ${ }^{186}$ Asherim were wooden posts or poles representing Asherah, a female deity in Canaanite religion. ${ }^{187}$ Asherim were to be destroyed. (12:3). Interestingly, nothing is said in Deuteronomy 12:2-3 about destroying the green trees associated with the old cult shrines. ${ }^{188}$. Again, it would seem, trees as such were to be respected and protected.

\section{B. Gifts of the Land: Fruit, Grain and Other Produce}

People in biblical times knew that the land was critically important. Though humans were to till the earth, ${ }^{189}$ it was God who cared for it, watered it, and caused it to bring forth of its bounty. ${ }^{190}$ Biblical tradition also affirmed God's care for the land and growing things, wholly apart from human needs or even presence:

Who has cleft a channel for the torrents of rain,

and a way for the thunderbolt,

to bring rain on a land where no man is,

on a desert in which there is no man;

185. See von Rad, Deuteronomy: A Commentary at 133 (cited in note 70).

186. See part V.B.2.

187. See von Rad, Deuteronomy: $A$ Commentary at 115 (cited in note 70); G. Emest Wright, Biblical Archaeology 6-7 (Westminster Press, 1960).

188. Compare Deut 16:21, which prohibits planting trees as Asherim by the altar at the one place. Of course, if trees were regarded as Asherim in Deut 12:1-3, they too would have been subject to destruction as such.

189. Gen $2: 5,15 ; 3: 23$-all in J tradition.

190. Psalms 65:9-13; 104:14-15. 
to satisfy the waste and desolate land,

and to make the ground put forth grass? (Job 38:25-27). ${ }^{191}$

The land provided for cattle, and it was the source of all agricultural crops. Such understanding is implicit in the "cultic calendar" of agricultural harvest ceremonies. ${ }^{192}$ Appreciation and respect for the land's yields comes to expression in several biblical laws and related texts. The gifts of the land were ultimately gifts from God. These gifts were to be used appropriately, and not taken for granted. As previously noted, the land's bounty was to be enjoyed not only by the biblical people and their cattle, but also by wildlife. ${ }^{193}$

\section{The Land of Milk and Honey: Numbers 13:17-33}

As in earlier narrative texts, so here in the PC, the promised land is described as a land "that flows with milk and honey." (Num 13:27). ${ }^{194}$ It was also a land of pomegranates and figs, and grapes so abundant or large that to carry a single cluster required two men with a pole. (13:23-24). These narratives probably date from relatively early $\mathrm{J}$ or $\mathrm{E}$ sources. Later accounts of life in the promised land do not indicate such preternatural fertility or abundance; but several biblical and inter-testamental texts do look for a superabundance of fruit crops in the future, messianic age. ${ }^{195}$ Because the land was already occupied by Canaanites and other peoples, the Israelites would not immediately gain entrance to or ascendency over it. The books of Joshua and Judges subsequently undertake to describe the Israelites' "conquest" of the land and their early years of tenuous occupancy there.

191. See also Psalm 104:10-13, 16-18. See generally Tucker, $116 \mathrm{~J}$ of Biblical Lit (cited in note 10).

192. See text accompanying notes 207-208.

193. See part VI.F.2.

194. See also Exod 3:8 and Num 14:8. Compare Num 16:13, where two dissidents complain that Moses took them out of "a land flowing with milk and honey," namely Egypt! Aldo Leopold once complained, "Conservation is getting nowhere because it is incompatible with our Abrahamic conception of land. We abuse land because we regard it as a commodity belonging to us." (Aldo Leopold, A Sand County Almanac, and Sketches Here and There, viii (Oxford U Press, 1949). Leopold explained, "Abraham knew exactly what the land was for: it was to drip milk and honey into Abraham's mouth." Id at 20405. Actually, biblical tradition does not characterize the promised land as one flowing with "milk and honey" until the time of Moses, several centuries after Abraham; moreover, no biblical text authorizes Abraham (or anyone else) to exploit or abuse the land.

195. See Richard Hiers, Jesus and the Future: Unresolved Questions for Understanding and Faith 72-86 (John Knox Press, 1981). 


\section{Abundant Harvests but only on Condition of Continuing} Fidelity

Deuteronomy 7:12-14: Righteousness and prosperity. If the Israelites remain faithful to YHWH and keep his commandments, He will cause them to multiply, and also bless and multiply their fruit and produce, grain, wine, oil, and cattle. There would be no barren male or female among them or among their cattle. (Deut 7:14). Again, we see the understanding that it is YHWH who gives the increase-but only if His people keep the covenant He had made with them. There would be no peace or prosperity otherwise..$^{196}$

Deuteronomy 11:8-17: Abundance and the peril of apostasy. As in several earlier texts, again, the land of promise is said to be "a land flowing with milk and honey." (Deut 11:9). Here, it is also said to be "a land of hills and valleys," watered by rain from heaven - "a land which YHWH your God cares for; the eyes of YHWH are always upon it, from the beginning of the year to the end of the year." (11:11-12). If the Israelites remain faithful to YHWH and love and serve Him with all their hearts and souls, says Moses, YHWH will continue to provide rain in season, assuring bountiful crops of grain, wine and oil, and providing grass in the fields for their cattle. (11:1315). But if they worship other gods, YHWH will "shut up the heavens," so that there would be no rain; the land will yield no fruit, and the Israelites will "perish quickly off the good land" which YHWH had given them. ${ }^{\text {.9 }}$ Several other biblical texts concerning agricultural conditions in later times attribute drought and crop failure to YHWH's disgust with His people who have forgotten Him, turned to other gods, and failed to meet their covenant obligations. ${ }^{198}$ Among the reasons turning to other gods is condemned, is that such worship fails to acknowledge YHWH as the source of life and its blessings. ${ }^{199}$

Leviticus 25:18-19. Like several other biblical traditions, this $\mathrm{H}$ text assures the community that the land of promise will produce abundant fruit provided the Israelites remain faithful to YHWH and

196. See also Prov 3:9-10; Haggai 1:7-11; 2:15-19; Mal 3:9-12. See also Gaster, Myth, Legend and Custom in the Old Testament 481-82 (cited in note 72) (as to 2 Sam 21:1-2).

197. See part VII.D.

198. See, for example, 1 Kings 17:1; 18:46; Amos 4:6-9; Haggai 1:2-11; Zech 10:1-2; Mal 3:512.

199. See, for example, Jer 2:4-28; Hosea 2:1-13. 
his laws. ${ }^{200}$ As generally in biblical perspective, it is understood that YHWH is the ultimate source of all good harvests. But his people should not presume upon his favor. The implication is that their good harvests and security will last only so long as they keep covenant with $\mathrm{YHWH}^{201}$

Deuteronomy 28:1-69: Further blessings or ruin? Here Moses (or YHWH) exhorts the Israelites to observe all the commandments set out in the foregoing chapters of the Deuteronomic Code. ${ }^{202}$ The exhortation promises future blessings, provided the Israelites obey YHWH's voice. These blessings would come in the form of abundant "fruit of the ground," cattle and other flocks (Deut 28:4, 11), and rain for the land in its seasons. (28:12). But if the Israelites fail to obey YHWH's voice and neglect to keep all his commandments, vicious enemies shall come upon them; ${ }^{203}$ and the "fruit" of this ground, along with their cattle and other flocks would be destroyed by pestilence, fiery heat, drought, and mildew. More ominously, "the heavens over your head shall be brass, and the earth under you shall be iron. YHWH will make the rain of your land powder and dust; from heaven it shall come upon you until you are destroyed." (28:23-24). Then, instead of having other animals as food, ${ }^{204}$ the Israelites' bodies will "be food for all birds of the air, and for beasts of the earth." (28:26). ${ }^{205}$ Writing during the time of the exile, the author of these verses knew that Israelite tenure on the promised land had come to an end. ${ }^{206}$ The land and its abundant yields were YHWH's to give, but also his to take away.

\section{Applied Genetics}

Leviticus 19:19 provided that Israelites (or Judahites) were not to sow their fields "with two kinds of seed." The purpose of this law may have been either to preserve preferred genetic strains or to facilitate harvesting by having only one crop growing in a given field at the same time. Or both purposes may have been intended. The

200. See, for example, Deut 6:1-15; 7:12-14; 8:6-20. Compare Haggai 2:15-19; Mal 3:9-12.

201. See also Lev 26:1-26.

202. The substantive provisions of that code probably concluded either with Deut 25 or 26 .

203. Compare Deut 27.

204. Compare Gen 9:2-3.

205. But see Lev 26:21-22; Deut 32:24; Ezek 39:45, 17-20; where wild beasts act as agents of YHWH's judgment. Such texts may have inspired the denouement scene in Clive Staple Lewis's novel, That Hideous Strength: A Modern Fairy-Tale for Grownups (MacMillan, 1965).

206. See Lam 5:19-22. 
text does not, of course, advocate monoculture, but refers only to a landowner's or farmer's particular field during a given planting season. Under this law farmers could sow one field with one kind of seed, and the next field with another, or even practice crop rotation.

\section{Responding to YHWH and to Those in Need}

Just as the land was YHWH's, so also were its products. Regularly biblical tradition views the fertility of orchards and fields as YHWH's gift to his people. In his sovereignty over creation, YHWH could give, or withhold these gifts. Israelites were to acknowledge YHWH as the giver by offering some of these products back to Him. The major agricultural festivals ordained in RD (Exod 34:22-24), the CC (Exod 23:14-17), H (Lev 23:1-44), and the revised Deuteronomic Code (Deut 16:1-17) were occasions for thanksgiving and celebration before YHWH who had provided his people with the land's abundant produce. These festivals, sometimes characterized by later interpreters as "the cultic calendar," included the "feast of unleavened bread" (later known as Passover), the "feast of first fruits" (also known as the "feast of weeks" or Pentecost), and the end of harvest season "feast of ingathering" or "feast of booths." Israelites also were to observe covenant law requirements expressing YHWH's compassion and concern for those unable to supply their own needs.

\section{a. Offerings to $Y H W H$.}

Deuteronomy 26:1-11. Once the Israelites were established in the promised land, they were to take some of the "first fruits" or first pickings of their initial harvest, put them in a basket, and take them to "the place," give it to "the priest," and make the recitation set out in Deuteronomy 26:5-10b. It is not clear whether this offering was to be repeated in subsequent years, or only on the occasion of the first harvest in the new land. The underlying assumption, again, is that the land is YHWH's. Thus the first fruits are to be offered to Him in recognition that it is $\mathrm{He}$ who causes the land to bring forth. ${ }^{209}$

207. See also Exod 12:1-20, 43-49.

208. See generally Theodor H. Gaster, Festivals of the Jewish Year: A Modern Interpretation and Guide 31-104 (Morrow Quill, 1978; Sloane, 1953).

209. See also Deut 26:12-15, discussed below. 


\section{b. Provisions for those in need.}

Both $\mathrm{D}$ and $\mathrm{H}$ include laws providing a "safety net" or welfare for the poor-typically widows, orphans, and resident aliens who lacked the means to provide for themselves. Such persons were entitled to "glean" in the fields and orchards following the first harvests. The story of Ruth exemplifies this arrangement. ${ }^{210}$

Deuteronomy 24:19-22: Gleaning privileges: the sojourner, the fatherless. This law states that landowners are not to go back after forgotten sheaves, are not to glean grapes after the first picking, and also, are not to pick fruit from their olive trees a second time. It does not explicitly name "the poor" as beneficiaries of these provisions; instead, it refers to the "the fatherless" (orphans) and widows-along with sojourners (resident aliens). This law and its counterparts in $\mathrm{H}$ accord with the understanding that the land and all that it provides are, ultimately, YHWH's, and that YHWH wants it to be used for His own purposes which here focus on the needs of those otherwise unable to support themselves. Implicit also, perhaps, is the perception that the gifts of the land are not to be wasted.

Leviticus 19:9-11: Leaving part of the harvest for the poor. These laws apply to land owners and also, presumably to their families and their servants or hired hands. Reapers are not to harvest their grain fields all the way to the edges or borders; and they are not to go back a second time to pick or cut what they had missed or left to ripen the first time around. Likewise, grape-pickers were to leave some grapes on the vines, and were not to pick up grapes that had fallen to the ground. The grain and grapes that were left were for the poor and sojourners, those who did not own land or were otherwise unable to support themselves. ${ }^{211}$ Though not mentioned, it may have been assumed that wildlife also would benefit from such laws. ${ }^{212}$ Other provisions also offered assistance to the poor. The Deuteronomic Code provided for the third year tithe; while the Holiness Code established an annual cycle of festivals and offerings.

Deuteronomy 26:12-15: The third-year tithe. Deuteronomy 14:22-27 required Israelites to tithe, that is, to give one-tenth of their harvests each year. They were to eat this offering before YHWH at

210. See Ruth 2.

211. See also Lev 23:22. See generally Hart, The Spinit of the Earth at 77-81 (cited in note 161).

212. Compare provisions for the sabbatical year, part VI.F2. 
"the place" every year. But if the way was too long, they might turn the tithe into money, take the money to "the place," and buy food there to "eat before YHWH." Deuteronomy 14:28-29, however, refers to a tithe every third year. This tithe was to be brought to the local towns and given to the Levite, the sojourner, the fatherless, and the widow. It is not clear how this third-year tithe was thought of in connection with the annual tithe mandated in Deuteronomy 14:22-27. The present text is related to the provisions of Deuteronomy 14:2829. In both, the beneficiaries are the Levite, the sojourner, the fatherless, and the widow. ${ }^{213}$

The stipulated prayer, which was to be uttered "before YHWH" (Deut 26:13), consists partly of a profession that one has properly kept the tithing law, and partly of a petition to YHWH to "look down ... from heaven" and continue to bless Israel and "the ground" which He had given them. (26:13-15). Here the ground is characterized as "a land flowing with milk and honey." From the context, it would seem that this prayer was to be addressed to YHWH in each town, rather than at the one "place." Both the thirdyear tithe and the accompanying prescribed prayer recognize YHWH as the one who gives both the land and its produce.

Leviticus 23:4-44: The annual cycle of festivals and offerings. This chapter summarizes the major agricultural festivals and offerings to be presented in connection with them. Some are grain or "cereal" offerings, and others involve sacrificing animals. Curiously, animal sacrifices are not specifically mentioned in connection with the descriptions here of either Passover (Lev 23:4-8) or the Day of Atonement. (23:26-32). Leviticus 23:22 presents another version of the "gleaning" law limiting exploitation of the land and providing for the needs of the poor and the sojourner. ${ }^{214}$ This provision follows a series of laws governing celebration of the feast of weeks (23:15-21), but in its terms appears to apply to all harvests. The revised "cultic calendar" laws in Deuteronomy 16 require that property owners include not only their own families and servants, but also Levites, ${ }^{215}$

213. See part V.B.2. (as to the Deuteronomic reform). To facilitate that reform, Deut 18:18 provided that local Levites who wished to move to Jerusalem might do so and there enjoy the same status and perquisites as those Levites (priests) who had previously officiated at the temple. Since local shrines had been closed, Levites who remained outside of Jerusalem were now unemployed and in need of assistance.

214. Compare Lev 19:9-11 \& Deut 24:19-20. Under such laws, the poor had a right to engage in such gleaning. Compare Prov 29:7: "A righteous man knows the rights of the poor."

215. See note 213 . 
sojourners (aliens), orphans ("the fatherless"), and widows when they celebrated the feast of weeks (16:11) and the feast of booths. (16:13-14). There were no food stamps, Aid to Families with Dependent Children (AFDC), or other social welfare provisions in those days. Property owners were not the only ones entitled to benefit from the gifts of the land.

Deuteronomy 23:24-25: Grapes and grain-snacks for passing neighbors. Contrary to modern private property concepts, this law presupposes that neighbors might lawfully enter one another's vineyards and grain fields without thereby trespassing. Moreover, visiting neighbors might eat as many grapes as they wished and pluck heads of standing grain with their hands. ${ }^{216}$ But they were not to carry off any grapes in containers, nor were they to cut grain with sickles. Implicitly, such neighbors might eat to satisfy their immediate hunger, but were not to take crops home with them to eat later or sell for profit.

\section{The New Covenant with All Creation.}

Many of the biblical writers, particularly the prophets, looked for a time in the future when YHWH would act on behalf of his people, or even of all humankind, and establish his beneficent rule over all creation. Two texts anticipate that in this future era, YHWH would remove or banish wild beasts from the restored land of Judah, ${ }^{217}$ perhaps relocating them elsewhere. Nowhere is anything said that would sanction destroying or exterminating any species. As in the $\mathbf{P}$ creation story, the story of the ark, and the $\mathrm{P}$ covenant in Genesis nine, throughout biblical tradition, all kinds of creatures are understood to have been made by God, and therefore worthy of existence. Some of the prophets expressly declared that other creatures would be present in the coming or messianic age. One in particular, Hosea, anticipated that YHWH would make a new covenant with Israel that would include other creatures as well.

\section{A. Hosea 2:18-19: A New Covenant with all Creatures}

Hosea two begins with a series of threats and warnings of judgment against Israel for her faithlessness. Yet beginning at verse 14, the prophet begins to speak of YHWH's intention to redeem

216. But see Mark 2:23.

217. Lev 26:6; Ezek 34:25. 
Israel, and in verse 18 , to make a new covenant with her. This covenant, like God's covenant with humans "and every living creature" after the flood (Gen 9:10-12,15-17), would be all-inclusive:

And I will make for you a covenant on that day with the beasts of the field, the birds of the air, and the creeping things of the ground; and I will abolish the bow, the sword, and war from the land; and I will make you lie down in safety. ${ }^{218}$

In effect, this covenant establishes the conditions particularized in Isaiah's promise that in the coming messianic age, wolves, lambs, leopards, little goats, cattle, children, cows, bears, and poisonous snakes would live together in peace, with no more hurting or destroying. For then the earth would be "full of the knowledge of YHWH as the waters cover the sea." (Isaiah 11:6-9). In Hosea's vision of the messianic age, this new covenant apparently would mark the end of all hunting, killing and hurting between humans and animals, and among the various kinds of animals. Even the "creeping things of the ground"-the smallest of creatures-would be included in this new covenant. ${ }^{219}$ In effect, the originally harmonious relations between human beings and other creatures that once existed in the Garden of Eden would be restored. ${ }^{200}$ Under this new covenant, in this new age, the curses that once "infected the ground"221 would be removed, and the earth would again bring forth abundantly. (Hosea 2:21-23). ${ }^{22}$ Other biblical visions of the future make clear what may be implicit in Hosea 2:18-23, that the abundant vegetation and harvests in this restored creation would benefit both humans and other creatures as well. ${ }^{23}$

\section{B. Isaiah 11:6-9: The Classic "Peaceable Kingdom" Text}

Here the prophet offers a vignette of the peaceable conditions YHWH would cause to obtain in the messianic age-that time in the future when He would make things right on earth. ${ }^{24}$ These verses follow an explicitly messianic text, that is, one that looks for YHWH

218. Hosea 2:18.

219. See also Gen 6:19-20; 7:8, 14 and 8:17-19 ("every creeping thing . . ." and God's covenant with "every living creature ... for all generations" in Gen 9:8-17.) See part III.

220. See Simkins, Creator and Creation at 219 (cited in note 3).

221. Gen 3:17-18; 4:12.

222. See also Amos 9:13-14.

223. See, for example, Jer 31:27-28; Ezek 17:22-23, 36:8-11; Joel 2:21-23; Matt 13:31-32; Mark 4:30-32; Luke 13:18-19. On the place of "nature" in biblical eschatology, see generally W. Sibley Towner, The Future of Nature, 50 Interpretation 27-35 (1996).

224. See Matt 6:10: When God's kingdom comes, His will would be done on earth. 
to establish a descendant of David as the righteous king who would accomplish YHWH's purposes. (11:1-5). Isaiah 11:6-9 anticipates that all creation would once again live together in peace:

The wolf shall dwell with the lamb, and the leopard shall lie down with the kid, and the calf and the lion and the fatling together, and a little child shall lead them.

The cow and the bear shall feed; their young shall lie down together; and the lion shall eat straw like the ox.

The sucking child shall play over the hole of the asp, and the weaned child shall put his hand on the adder's den. They shall not hurt or destroy in all my holy mountain; For the earth shall be full of the knowledge of YHWH as the waters cover the sea.

According to the $\mathrm{P}$ creation story, God originally intended humans and all other creatures to live peaceably together. At first, humans were to have "dominion" over other creatures, but both humans and animals were vegetarians. (Gen 1:26-31). Humans were to eat of "any plant yielding seed," and "every tree with seed in its fruit." (1:29). Other creatures were to have "every green plant for food." (1:30). After the flood, humans began to take other creatures for food, and, presumably (though it is not explicitly stated), some other creatures became predators, preying upon others. (9:2-3). Isaiah 11:6-9 looks for the restoration of that original era of peace and harmony; other creatures, at any rate, would no longer eat each other. $^{225}$ Implicitly, it seems, humans would no longer kill other creatures for food, either: "They" in Isaiah 11:9 seems to mean all living creatures including humans. "They shall not hurt or destroy in all my holy mountain; for the earth shall be full of the knowledge of YHWH as the waters cover the sea." 226

225. Compare Simkins, Creator and Creation at 225-27 (cited in note 3), urging that this text is concerned only with "violence that occurs between the human and the animal world," not with "violence within the animal world." On its face, Isaiah 11:6-9 anticipates that, in the new age, neither kind of violence would any more occur. See Donald E. Gowan, Eschatology in the Old Testament 104 (Fortress Press, 1986). See also Jay B. McDaniel, Of God and Pelicans: A Theology of Reverence for Life 14 (John Knox Press, 1989): Isaiah's vision represents "an end to predator-prey relationships." Ezek 47:7-12 suggests that this prophet believed that in the new age, the human diet would consist of fish and fruit. See generally Richard H. Hiers \& Charles A. Kennedy, The Bread and Fish Eucharist in the Gospels and Early Christian Art, 3 Perspectives in Religious Studies 20-47 (1976).

226. Reference to "the fatling" (Isaiah 11:6) does not necessarily imply that animals formerly slaughtered for food would still be fattened and slaughtered in the messianic age. Instead, the term may refer simply to animals (or young animals) that in earlier times would 
The prospect that infants and children would be safe from once poisonous snakes (Isaiah 11:8), ${ }^{27}$ implicitly revokes the "curse" put upon relations between humans and serpents in Genesis 3:15. It may be that the odd text about people picking up serpents in Mark 16:1718 reflects some early Christians' belief that the messianic age had already commenced. Paul, on the other hand, evidently did not think that the time of enmity between people and poisonous snakes was yet over. $^{28}$ A later disciple of Isaiah's, writing late in the sixth century B.C.E., likewise looked for "the peaceable kingdom."

\section{Isaiah 65:17-25: New Heavens, New Earth, and the Peaceable Kingdom}

This later Isaianic prophet, sometimes designated "Third Isaiah," writing soon after the exile, anticipated that in, or at the beginning of the new or messianic age, YHWH would "create new heavens and a new earth." (Isaiah 65:17). What is meant seems to be more in the nature of a radical transformation of the conditions of life on earth. ${ }^{29}$ Jerusalem would still be there (65:19a), but there would be no more weeping or cries of distress, no more infant mortality, and human life-span would extend at least to a hundred years. (65:19b-20). People would build houses, plant vineyards, and enjoy them. There would be no calamities (or sudden terror); YHWH would hear and answer their desires or prayers even before they called upon Him. Moreover, in words echoing Isaiah 11:6-9, Third Isaiah assured his hearers or readers, humans and animals would dwell together in peace:

The wolf and the lamb shall feed together,

the lion shall eat straw like the ox;

and dust shall be the serpent's food.

They shall not hurt or destroy

in all my holy mountain, says YHWH. ${ }^{20}$

In effect, all living beings would return to the vegetarianism of primordial times. (Gen 1:29-30).

have been fattened for slaughter.

227. See also Isaiah 65:25.

228. Acts 28:2-6. From Paul's standpoint, even though "the whole creation" was in the process of undergoing a new birth (Rom 8:17-22), the new age had not yet come. See James A. Nash, In Flagrant Dissent in Derr, Environmental Ethics and Christian Humanism at 109 (cited in note 133) (noting New Testament expressions of "hope for cosmic redemption").

229. See also, for example, Hosea 2:21-22, 3:5; Joel 3:18; Amos 9:11-15; Haggai 2; and Zech 14.

230. Isaiah 65:25. 


\section{CONCLUSIONS}

How contemporary individuals or "schools" may view the authority and relevance of biblical tradition, of course, is another question. ${ }^{231}$ Some regard biblical tradition as scripture in a strong sense, as holy writ, and thus providing direct answers to contemporary issues; others may consider the Bible a record of what serious religious people in earlier times believed, which may sometimes illuminate latter-day Jewish and Christian moral reflection. However interpreted, biblical law and covenant witness to an understanding that God's care extends not only to human beings, but also to the well being of all kinds of living creatures.

Discussions have moved well beyond the stage of responding to criticisms of biblical tradition for subsequent and current patterns of environmental exploitation and degradation. ${ }^{222}$ Particularly in the last few years, a great many excellent studies have examined biblical texts to see what resources and warrants they may provide for developing religiously grounded environmental ethics and related ethics of concern for all life forms. ${ }^{23}$ These studies-and perhaps also the present article-make it clear that contemporary concerns for the well-being of the earth (or biosphere), humans and other species of living beings, and individual creatures of all species who share this planet's various habitats, need not be grounded upon some kind of nature-mysticism or neo-paganism, as some proponents and opponents of such concerns sometimes contend. ${ }^{24}$ Rather, such concerns may.be seen to derive directly from the kind of theocentric or monotheistic belief in God as creator and valuer of all that is,

231. See generally, Richard H. Hiers, Ecology, Biblical Theology, and Methodology, 19 Zygon 43-59 (1984); Walter Wink, Ecobible: The Bible and Ecojustice, 49 Theology Today 465-77 (1993). Conservatives and evangelicals divide over the extent to which biblical tradition warrants environmental concern and concern for other species. Some ground such concern in biblical texts. See, for example, Ronald J. Sider, Message from an Evangelical: The Place of Humans in the Garden of Eden, 17 Amicus 12-14 (1995). Generally, however, these groups tend to ignore or hold negative views as to these concerns. See generally, James L. Guth, et al, Faith and Environment: Religious Beliefs and Attitudes on Environmental Policy, $39 \mathrm{Am} \mathrm{J}$ of Pol Sci 364-82 (1995).

232. See note 7 and accompanying text. See also, Theodore Hiebert, Re-Imaging Nature: Shifts in Biblical Interpretation, 50 Interpretation 36-46 (1996); Jeanne Kay, Human Dominion over Nature in the Hebrew Bible, 79 Annals of the Assn of Am Geographers 21432 (1989); Kay, Concepts of Nature in the Hebrew Bible at 309-327 (cited in note 15); Pope John Paul II, For the Celebration of the World Day of Peace, 30 Natural Resources J 1-8 (1990); Simkins, Creator and Creation (cited in note 3 ).

233. See note 3 and accompanying text.

234. See Hayden, The Lost Gospel of the Earth at 63-66 (cited in note 10). 
affirmed in biblical tradition. ${ }^{235}$

Obviously biblical laws and covenants do not set out a systematic program of environmental protection. And most of these laws and covenants relate primarily to human beings, in the first instance, to Israelites, Judahites, and Jews. Most contemporary environmentalists likewise tend to consider human well-being of first importance. Yet biblical laws and covenants also include other life forms in the realm of valued being. God who made all that exists, including all kinds of living creatures, saw and affirmed that these were all "good," indeed, "very good." (Gen 1:1-31). Notwithstanding the pervasive violence that had corrupted the earth, the biblical narrative tells that, even though God had determined to "make an end of all flesh," He instructed Noah to construct a vessel and bring on board pairs of every kind of breathing creature, in order to keep alive all species. After the flood, not only humans, but all kinds of air-breathing creatures were ordered to "be fruitful and multiply." And then, as the story is told, God made his covenant not only with the forebears of all humankind, but with the forebears of all living species, an "everlasting covenant between God and every living creature of all flesh that is upon the earth" which would be "for all future generations," never again to allow flood waters to destroy the earth or all flesh. Thus God would affirm and sustain not only human history, but also "natural history"-or the lives and experiences of all kinds of creatures in this world so long as it continued.

Many biblical laws accord with understanding that God created, covenanted with, and cares for all creation. Unlike some of their neighbors and ancestors, Israelites were no longer to sacrifice their first-born sons or daughters. A domestic animal might be sacrificed instead-implying that in some way the animal's life was the equivalent of the human life. When either wild or domestic animals were killed for food, their blood, understood as the locus of life, was not to be destroyed by human consumption, but instead was to be returned to the ground, whence their life had come, and thus to God. A number of different kinds of laws specifically concerned animals' well-being. Some reflected special appreciation for relationships between animal mothers and their young. Some spelled out duties to

235. See generally, H. Richard Niebuhr, Radical Monotheism and Western Culture at 24-63 (Harper and Brothers, 1960), and Sturm, Faith, Ecology and the Demands of Social Justice (cited on the first page of this article, biographical note). 
assist distressed animals. One evidently was intended to promote wildlife conservation. Another to avoid unnecessary cruelty to animals. And several provided that animals, like humans, should enjoy periods of rest, and that even wildlife should be allowed to enjoy the fruits of human agriculture. Several more laws, though not directly related to animal well-being, showed generally positive concerns of one sort and another.

A number of laws had to do with care for the land-understood as given into Israel's possession, but ultimately God's to take back if Israel failed to comply with his laws and covenants. Several laws concerned treatment of trees, and others set out duties regarding utilization of harvests to honor God and also care for persons in need.

The original Genesis covenant between God and "every living creature of all flesh" clearly expressed YHWH's concern for the well-being of both humans and other living things throughout the course of history. The new covenant, anticipated and promised by Hosea and Isaiah, looked for God's continuing care for humans and all other living beings in the future, messianic age on a transformed earth. Together, these two covenants embrace all time, both historical and messianic. Thus in both covenants and for all time, it was understood that God's people were to enjoy the good world which God had made and would re-make, and there share its blessings with all those other creatures which He likewise had brought into being for His own purposes and found to be "very good." 